\title{
Geology of the
}

\section{Dewey Quadrangle}

\section{Wyoming-South Dakota}

GEOLOGICAL SURVEY BULLETIN 1063 -B

Prepared on behalf of the U.S. Atomic Energy Commission and published with the permission of the Commission 


\section{Geology of the}

\section{Dewey Quadrangle}

\section{Wyoming-South Dakota}

By DONALD A. BROBST

GEOLOGY OF URANIUM DEPOSITS IN SOUTHERN BLACK HILLS

GE OLOGICALSURVEY B U L L T I N $1063-\mathrm{B}$

Prepared on behalf of the U.S. Atomic Energy Commission and published with the permission of the Commission

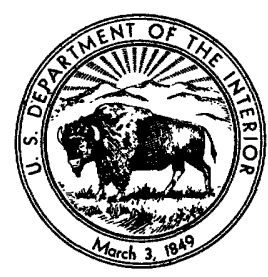


UNITED STATES DEPARTMENT OF THE INTERIOR

STEWART L. UDALL, Secretary

\section{GEOLOGICAL SURVEY}

Thomas B. Nolan, Director Washington 25, D.C. 


\section{CONTENTS}

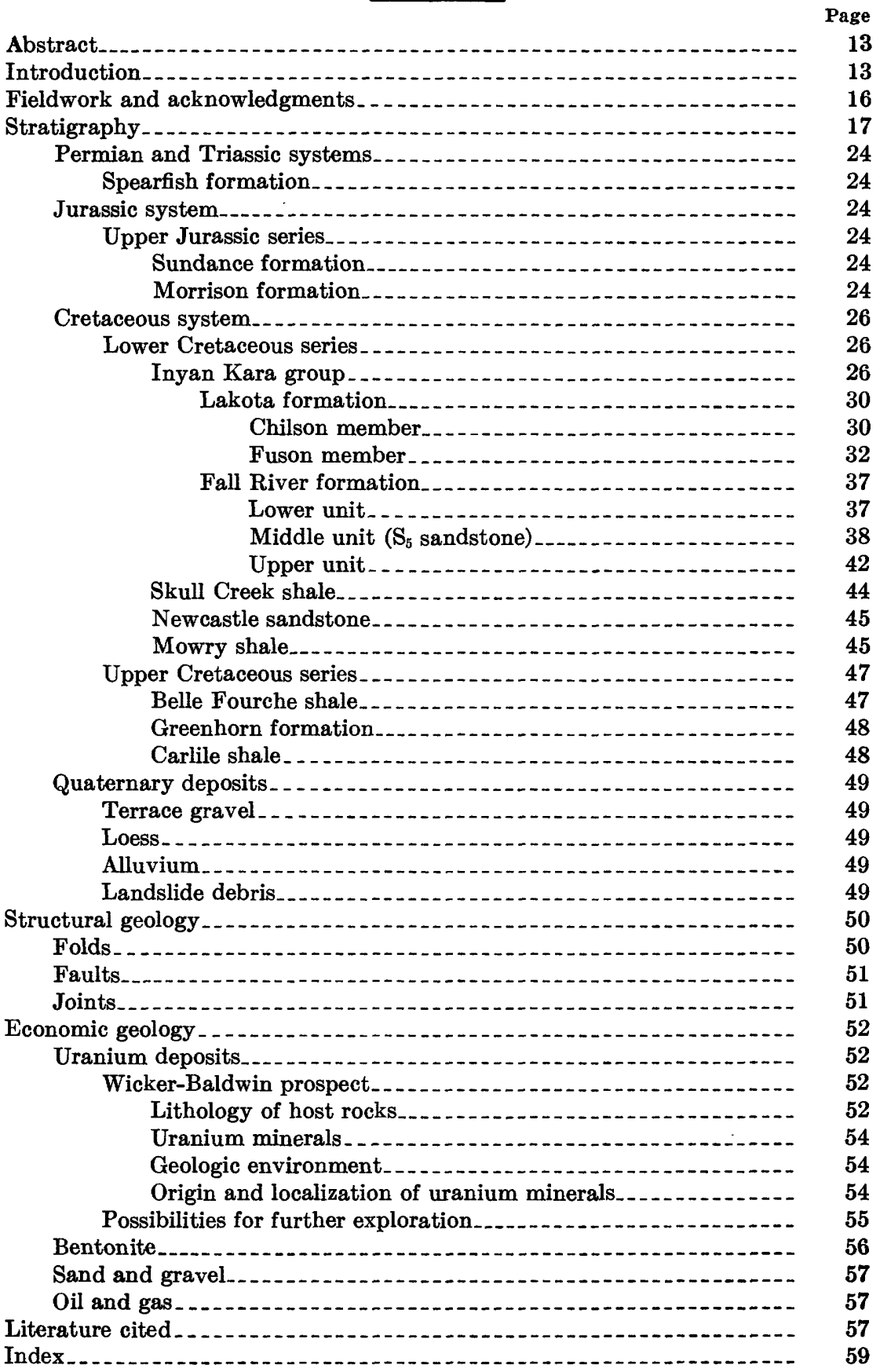




\section{ILLUSTRATIONS}

Page

Plate 5. Geologic map and sections of the Dewey quadrangle In pocket

6. Geologic map and section of Wicker-Baldwin urainum prospect, Weston County, Wyo In pocket

Figure 5. Index and general structure map of the Dewey area...... 14

6. Structure contour map of the Black Hills, S. Dak., and adjacent areas.

7. Structure contour map of the top of the $S_{3}$ sandstone of the Fuson member of Lakota formation in the northeastern part of the Dewey quadrangle

8. Isopach map of the $S_{5}$ sandstone in the Fall River formation in the northeastern part of the Dewey quadrangle . ........

9. Schematic drawing of possible relations of complex channel

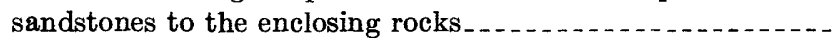

10. Schematic diagram of structure in the Skull Creek shale in NE1/4 sec. 21, T. 41 N., R. 60 W., Weston County, Wyo...

\section{TABLE}

TABLE 1. Stratigraphy of the western Black Hills and the Dewey quadrangle 


\title{
GEOLOGY OF URANIUM DEPOSITS IN SOUTHERN BLACK HILLS
}

\section{GEOLOGY OF THE DEWEY QUADRANGLE WYOMING-SOUTH DAKOTA}

\author{
By Donald A. Brobst
}

\section{ABSTRACT}

The Dewey quadrangle includes about 50 square miles on the southwest flank of the Black Hills in parts of Custer County, S. Dak., and Weston and Niobrara Counties, Wyo. About 2,000 feet of sedimentary rocks of Triassic to Late Cretaceous age is exposed. These rocks locally are covered by unconsolidated sediments of Quaternary age. The major structures from east to west are the Elk Mountains, part of the west-dipping Black Hills monocline; the Dewey terrace, west of the Elk Mountains ; and the west-dipping Fanny Peak monocline on the west side of the terrace. The Black Hills monocline and the Dewey terrace are cut by the vertical(?) northeast-trending Dewey fault. Uranium minerals occur in the rocks of the Inyan Kara group of Early Cretaceous age. Only the Wicker-Baldwin property in the Fall River formation has been mined. Deposits of Quaternary sand and gravel and thin beds of Upper Cretaceous bentonite might be of potential economic interest. Some oil and gas might be associated with rocks on the Dewey terrace.

\section{INTRODUCTION}

The Dewey quadrangle includes an area of about 50 square miles on the southwest flank of the Black Hills in parts of Custer County, S. Dak., and Weston and Niobrara Counties, Wyo. (figs. 5, 6, pl. 5). The Black Hills are an asymmetrical dome in western South Dakota and northeastern Wyoming. Figure 6 shows the general configuration of the dome on the top of the Precambrian rocks. The Precambrian rocks are exposed only in the central part of the uplift, approximately within the area encircled by the 5,000-foot topographic contour. Sedimentary rocks of Paleozoic, Mesozoic, and Cenozoic age are exposed around the core, the oldest rocks being closest to the core (Darton, 1904). Structure in the sedimentary rocks is similar to that shown in figure 6 .

The west side of the Black Hills borders the Powder River Basin at the Fanny Peak monocline on the west side of the Dewey terrace; thus, the Dewey quadrangle is astride this joining of regional structures (fig. 5). 


\section{GEOLOGY OF URANIUM DEPOSITS IN SOUTHERN BLACK HIILS}

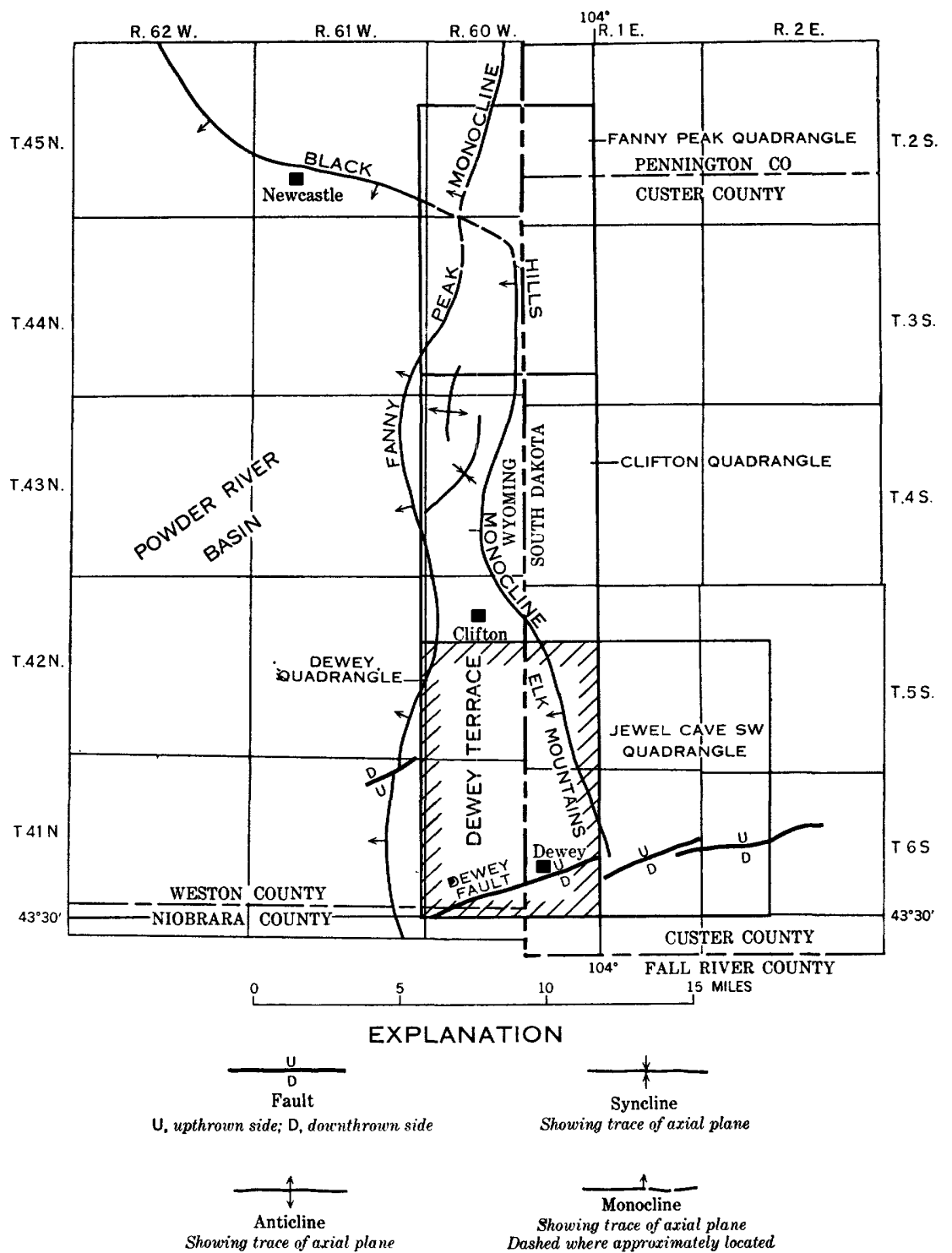

Figure 5.-Index and general structure map of the Dewey area, Wyoming-South Dakota. 


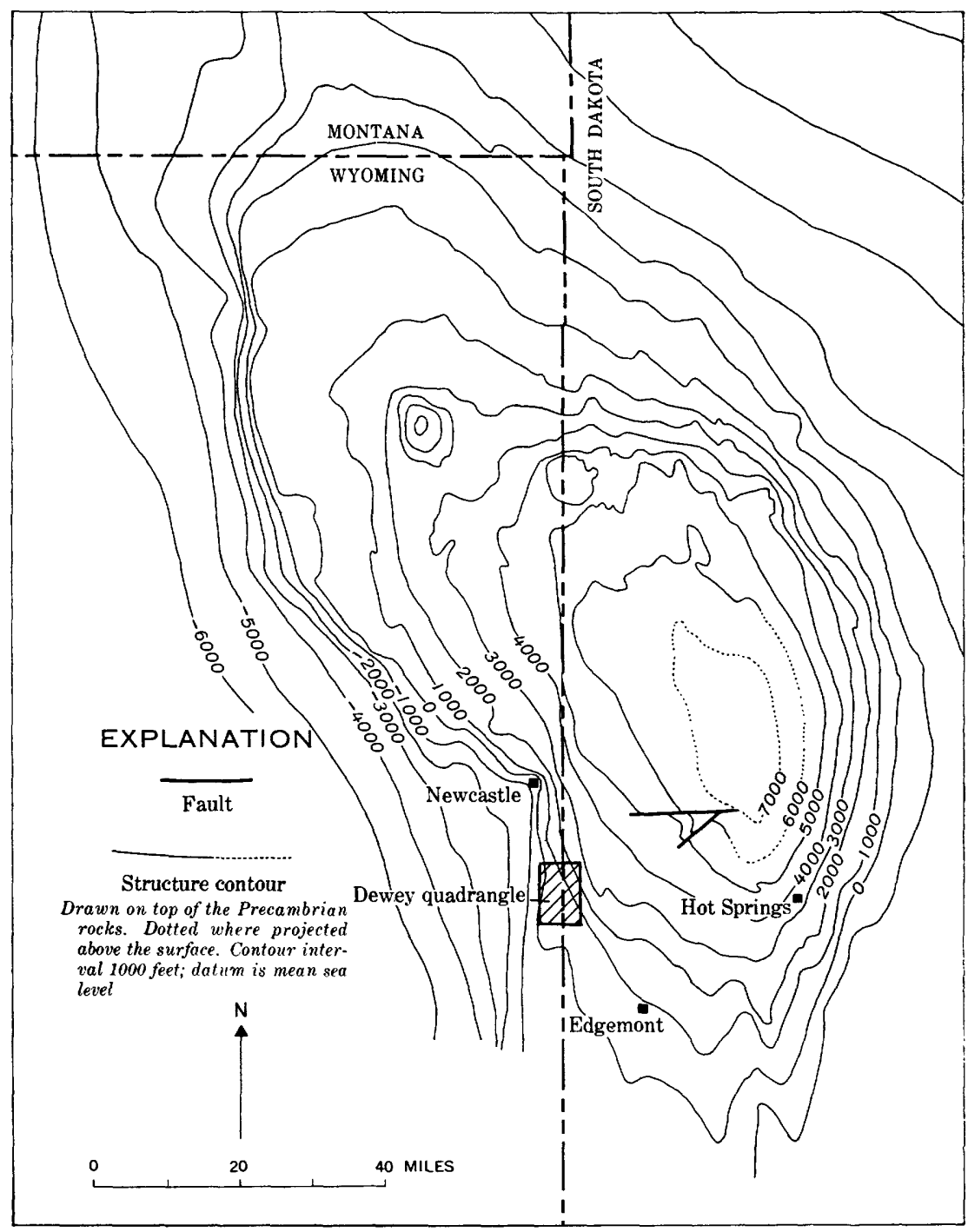

After Noble, Harder, and Slaughter, 1949

FigURe 6.-Structure contour map of the Black Hills, S. Dak., and adjacent areas. 
The northeastern third of the Dewey quadrangle is occupied by the Elk Mountains, a monoclinal ridge that dips gently to the west and is cut by many canyons. The east face of the mountains is an escarpment 300 to 800 feet high. West and southwest of the Elk Mountains are rolling hills of low relief on the Dewey terrace. On the west side of the terrace the Fanny Peak monocline dips about $25^{\circ} \mathrm{W}$. The topographic break in slope between the Elk Mountains and the low rolling hills to the west is at an altitude of about 3,800 feet. The altitude in the area ranges from 4,967 feet on Sullivan Peak in the Elk Mountains to 3,620 feet where Beaver Creek flows southward out of the quadrangle (pl.5).

The area is drained by Beaver and Line Creeks that flow south to the Cheyenne River. Rainfall of about 10 inches a year supports the growth of grass and of juniper and ponderosa pine on the Elk Mountains and on some hills to the west. Stockraising is the chief occupation in the region.

The community of Dewey, with a population of 40 , is on the Omaha, Nebr.-Billings, Mont., branch of the Chicago, Burlington \& Quincy Railroad about 25 miles southeast of Newcastle, Wyo., and 20 miles northwest of Edgemont, S. Dak. Secondary roads cross the quadrangle and connect the area with U.S. Highway 85 that runs northward 8 miles west of Dewey (pl. 5).

\section{FIELDWORK AND ACKNOWLEDGMENTS}

The rocks of the Inyan Kara group of Early Cretaceous age were mapped by the author in 1955 at a scale of $1: 7,200$. All other rocks were mapped at a scale of 1:20,000 with the assistance of J. B. Epstein in 1956. The information supplied by the residents of the area was most helpful and their cooperation is gratefully acknowledged.

The work in the Dewey quadrangle was done as part of a project on behalf of the Division of Raw Materials of the U.S. Atomic Energy Commission to study the geology and uranium deposits of the Inyan Kara group in the southern Black Hills from Hot Springs. S. Dak., to Newcastle, Wyo. (fig. 6). Some of the quadrangles mapped as a part of this project are shown in figure 5 .

Preliminary geologic maps at a smale of $1: 7,200$ have been published for the part of the Dewey quadrangle where rocks of the Inyan Kara group are exposed (Brobst, 1958a, b). 


\section{STRATIGRAPHY}

About 2,000 feet of sedimentary rocks of Triassic to Cretaceous age is exposed in the quadrangle. Regional and local descriptions of the formations are summarized in table 1. Stratigraphic units of particular importance to the present study, such as the Inyan Kara group, are described in greater detail below. The Spearfish formation of Permian and Triassic age and the Sundance and Morrison formations of Jurassic age are exposed chiefly east of the crest of the Elk Mountains. The rocks of the Inyan Kara group of Early Cretaceous age are exposed in the Elk Mountains. The Skull Creek shale, Newcastle sandstone, Mowry and Belle Fourche shales of Cretaceous age are exposed on the Dewey terrace to the west. The Greenhorn formation and the Carlile shale of Late Cretaceous age are exposed in small hogbacks 40 to 100 feet high on the west side of the Dewey terrace (pl. 5). The rocks of this area were first mapped and described by Darton (1904). 
GEOLOGY OF URANIUM DEPOSITS IN SOUTHERN BLACK HILLS

TABLE 1.-Stratigraphy of the western Black Hills

\begin{tabular}{|c|c|c|c|c|}
\hline \multirow{2}{*}{ Series } & \multirow{2}{*}{$\begin{array}{l}\text { Formation and } \\
\text { member }\end{array}$} & \multicolumn{3}{|c|}{ Western Black Hills } \\
\hline & & Lithology & Thickness (feet) & Remarks \\
\hline \multirow{6}{*}{ 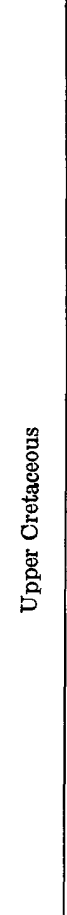 } & Carlile shale & Shale and sandstone. & 600 average & $\begin{array}{l}\text { Definition:Gilbert (1896, } \\
\text { p. 565). } \\
\text { Fauna: Cobban (1951, } \\
\text { p. 2187-2190). } \\
\text { Marine origin. }\end{array}$ \\
\hline & $\begin{array}{l}\text { Sage Breaks } \\
\text { shale member }\end{array}$ & $\begin{array}{l}\text { Mostly gray noncalcare- } \\
\text { ous shale. }\end{array}$ & Range, 200 to 300 & $\begin{array}{l}\text { Cobban (1951) Marine } \\
\text { origin. }\end{array}$ \\
\hline & $\begin{array}{l}\text { Turner sandy } \\
\text { member }\end{array}$ & Sandstone and shale. & $\begin{array}{c}160 \text { in Newcastle, } \\
\text { Wyo., area }\end{array}$ & $\begin{array}{l}\text { Definition: Rubey (1930, } \\
\text { p. 4); Cobban (1951). }\end{array}$ \\
\hline & $\begin{array}{l}\text { Lower un- } \\
\text { named mem- } \\
\text { ber }\end{array}$ & $\begin{array}{l}\text { Dark-gray shale contain- } \\
\text { ing calcareous and fer- } \\
\text { ruginous concretions. }\end{array}$ & 125 maximum & Cobban (1951). \\
\hline & $\begin{array}{l}\text { Greenhorn forma- } \\
\text { tion }\end{array}$ & $\begin{array}{l}3 \text { facies of limestone, } \\
\text { shale, and marl. }\end{array}$ & $\begin{array}{l}70 \text { to } 370 \text {. Thickest in } \\
\text { eastern Montana, } \\
\text { thins westward and } \\
\text { southward. }\end{array}$ & $\begin{array}{l}\text { Defined (in Colorado): } \\
\text { Gilbert (1896, p. 564). } \\
\text { Description in Black } \\
\text { Hills: Rubey (1930). } \\
\text { Marine origin. }\end{array}$ \\
\hline & Belle Fourche shale & $\begin{array}{l}\text { Gray to black shale with } \\
\text { some beds of benton- } \\
\text { ite. }\end{array}$ & $\begin{array}{l}550 \text { at Osage, Wyo; } 700 \\
\text { at Thornton, Wyo. }\end{array}$ & $\begin{array}{l}\text { Definition: Collier (1922, } \\
\text { p. 83). } \\
\text { Marine origin. }\end{array}$ \\
\hline
\end{tabular}


and the Dewey quadrangle, Wyoming-South Dakota

\begin{tabular}{|c|c|c|c|c|}
\hline \multicolumn{5}{|c|}{ Dewey quadrangle } \\
\hline Lithology & $\begin{array}{c}\text { Thickness } \\
\text { (feet) }\end{array}$ & Contact & $\begin{array}{c}\text { Measured } \\
\text { section } \\
\text { No. }\end{array}$ & Remarks \\
\hline \multirow[t]{2}{*}{$\begin{array}{l}\text { Gray shales and gray to } \\
\text { brown sandstone. }\end{array}$} & $136+$ & $\begin{array}{l}\text { Topnotexposed. Base } \\
\text { is top of uppermost } \\
\text { fossiliferous bed of } \\
\text { the Greenhorn lime- } \\
\text { stone. }\end{array}$ & 8 & $\begin{array}{l}\text { Only lower two members } \\
\text { exposed; see below. }\end{array}$ \\
\hline & & & & $\begin{array}{l}\text { Not exposed in the Dewey } \\
\text { quadrangle. }\end{array}$ \\
\hline $\begin{array}{l}\text { Mostly gray and brown } \\
\text { med i u }- \text { grained } \\
\text { sandstone and inter- } \\
\text { bedded shale. }\end{array}$ & $16+$ & $\begin{array}{l}\text { Top covered by allu- } \\
\text { vium. Basal bed is } \\
5 \mathrm{ft} \text { light-gray me- } \\
\text { dium-grained cal- } \\
\text { careous sandstone. }\end{array}$ & 8 & $\begin{array}{l}\text { Forms a small hogback west } \\
\text { of Greenhorn hogback in } \\
\text { sec. 18, T. 42 N., R. } 1 \text { E., } \\
\text { Weston County, Wyo. }\end{array}$ \\
\hline $\begin{array}{l}\text { Dark-gray shale with } \\
\text { calcareous and ferru- } \\
\text { ginous concretions. }\end{array}$ & $\begin{array}{l}\text { 120, esti- } \\
\text { mated }\end{array}$ & $\begin{array}{l}\text { Unit begins at the top } \\
\text { of the uppermost fos- } \\
\text { siliferous bed of } \\
\text { Greenhorn lime- } \\
\text { stone. }\end{array}$ & 8 & $\begin{array}{l}\text { Poorly exposed in a narrow } \\
\text { valley between hogbacks } \\
\text { of Turner sandy member } \\
\text { and Greenhorn limestone. } \\
\text { Fossils in limy concretions: } \\
\text { Inoceramus fragilio, Scaph- } \\
\text { ites larvaeformensis, Col- } \\
\text { lignonoceras woolgari and } \\
\text { Tragodosmocerasn.sp. Fos- } \\
\text { sil identifications by W. A. } \\
\text { Cobban. }\end{array}$ \\
\hline $\begin{array}{l}\text { Lower } 250 \text { ft soft gray } \\
\text { to brown calcareous } \\
\text { shale with interbed- } \\
\text { ded thin gray to } \\
\text { brown fossiliferous } \\
\text { limestone. Poorly ex- } \\
\text { posed. Upper } 25 \text { ft } \\
\text { mostly slabby thin- } \\
\text { bedded fossiliferous } \\
\text { gray to brown lime- } \\
\text { stone with interbed- } \\
\text { ded gray mudstone. }\end{array}$ & 275 & $\begin{array}{l}\text { Upper contact, see } \\
\text { above. Lower con- } \\
\text { tact gradational, } \\
\text { placed approxi- } \\
\text { mately where shale } \\
\text { changes color up- } \\
\text { ward from black to } \\
\text { gray and brown. }\end{array}$ & & $\begin{array}{l}\text { Forms hogback on west side } \\
\text { of Dewey terrace in sec. } 18 \text {, } \\
\text { T. } 42 \mathrm{~N} \text {., R. } 60 \text { W., Weston } \\
\text { County, Wyo. Abundant } \\
\text { Inoceramus labiatus in lime- } \\
\text { stone beds; identified by } \\
\text { the author. }\end{array}$ \\
\hline $\begin{array}{l}\text { Gray to black shale with } \\
\text { beds of bentonite; } \\
\text { weathers black. }\end{array}$ & $\begin{array}{l}\text { 400, esti- } \\
\text { mated }\end{array}$ & $\begin{array}{l}\text { Gradational upper } \\
\text { contact. Lower } \\
\text { contact top of Clay } \\
\text { Spur bentonite bed } \\
\text { of Knechtel and Pat- } \\
\text { terson (1956). See } \\
\text { text. }\end{array}$ & & $\begin{array}{l}\text { Only lower } 100 \mathrm{ft} \text { well ex- } \\
\text { posed. Exposed on west } \\
\text { side of Dewey terrace and } \\
\text { southwest of Dewey fault. } \\
\text { Oligonite concretions and } \\
\text { layers common in lower } 50 \\
\text { ft. See text. }\end{array}$ \\
\hline
\end{tabular}


GEOLOGY OF URANIUM DEPOSITS IN SOUTHERN BLACK HILLS

TABLE 1.-Stratigraphy of the western Black Hills

\begin{tabular}{|c|c|c|c|c|c|c|}
\hline \multirow{2}{*}{ Series } & \multirow{2}{*}{\multicolumn{3}{|c|}{$\begin{array}{l}\text { Formation and } \\
\text { member }\end{array}$}} & \multicolumn{3}{|c|}{ Western Black Hills } \\
\hline & & & & Lithology & Thickness (feet) & Remarks \\
\hline \multirow{7}{*}{ 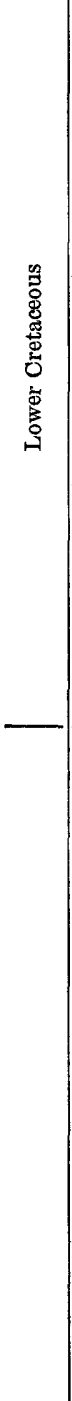 } & \multicolumn{3}{|c|}{ Mowry shale } & $\begin{array}{l}\text { Dark-gray siliceous shale } \\
\text { with thin beds of sand- } \\
\text { stone and bentonite. }\end{array}$ & $\begin{array}{l}165 \text { at Newcastle, } \\
\text { Wyo.; } 230 \text { at corners } \\
\text { of Montana, Wyo- } \\
\text { ming, and South } \\
\text { Dakota. }\end{array}$ & $\begin{array}{l}\text { Definition: Collier (1922, } \\
\text { p. 82). } \\
\text { Description:Rubey(1929) } \\
\text { marine origin. }\end{array}$ \\
\hline & \multicolumn{3}{|c|}{$\begin{array}{l}\text { Newcastle sand- } \\
\text { stone }\end{array}$} & $\begin{array}{l}\text { Lenticular beds of sand- } \\
\text { stone and shale and } \\
\text { lesser amounts of silt- } \\
\text { stone. }\end{array}$ & Range, 20 to 60 & $\begin{array}{l}\text { Definition: Hancock } \\
\text { (1920, p. 40). } \\
\text { General description: } \\
\text { Grace (1952). } \\
\text { Marine to marginal ma- } \\
\text { rine origin. }\end{array}$ \\
\hline & \multicolumn{3}{|c|}{ Skull Creek shale } & $\begin{array}{l}\text { Dark-gray to black soft } \\
\text { flaky shale with inter- } \\
\text { bedded sandstones and } \\
\text { siltstones, especially } \\
\text { near the top and bot- } \\
\text { tom. }\end{array}$ & 250 average & $\begin{array}{l}\text { Definition: Collier (1922, } \\
\text { p. } 79) \text {. } \\
\text { Marine origin. }\end{array}$ \\
\hline & \multirow{4}{*}{ 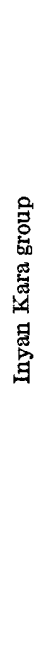 } & \multicolumn{2}{|c|}{$\begin{array}{l}\text { Fall River } \\
\text { formation }\end{array}$} & $\begin{array}{l}\text { Sandstone, siltstone, and } \\
\text { mudstone. }\end{array}$ & Range, 110 to 150 & $\begin{array}{l}\text { Defined by K. M. } \\
\text { Waagé (1959). } \\
\text { Terrestrial or marginal } \\
\text { marine. See text. }\end{array}$ \\
\hline & & \multirow{3}{*}{ 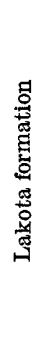 } & 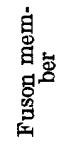 & $\begin{array}{l}\text { Mudstone, siltstone and } \\
\text { sandstone. }\end{array}$ & Range, 10 to 200 & $\begin{array}{l}\text { Defined by K. M. } \\
\text { Waagé (1959). } \\
\text { Terrestrial origin. See } \\
\text { text. }\end{array}$ \\
\hline & & & 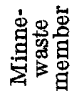 & Limestone. & Range, 0 to 80 & $\begin{array}{c}\text { In southern Black Hills } \\
\text { only. Absent in } \\
\text { Dewey quadrangle. }\end{array}$ \\
\hline & & & 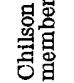 & $\begin{array}{l}\text { Sandstone, mudstone, } \\
\text { and siltstone. }\end{array}$ & Maximum about 450 & $\begin{array}{l}\text { Defined by Post and } \\
\text { Bell (1961). }\end{array}$ \\
\hline
\end{tabular}


and the Dewey quadrangle, Wyoming-South Dakota-Continued

\begin{tabular}{|c|c|c|c|c|}
\hline \multicolumn{5}{|c|}{ Dewey quadrangle } \\
\hline Lithology & $\underset{\text { (feet) }}{\text { Thickness }}$ & Contact & $\begin{array}{c}\text { Measured } \\
\text { section } \\
\text { No. }\end{array}$ & Remarks \\
\hline $\begin{array}{l}\text { Dark-gray siliceous } \\
\text { shale with thin beds } \\
\text { of sandstone and ben- } \\
\text { tonite. Weathers sil- } \\
\text { very gray. }\end{array}$ & 130 & $\begin{array}{l}\text { Upper contact, see } \\
\text { above. Lower con- } \\
\text { tact gradational } \\
\text { with Skull Creek } \\
\text { shale. Relation to } \\
\text { Newcastlesandstone } \\
\text { obscure. Poorly ex- } \\
\text { posed. }\end{array}$ & & $\begin{array}{l}\text { Unit exposed over } 15 \mathrm{sq} \text { mi } \\
\text { west of Line Creek and } \\
\text { south of Dewey fault. Sup- } \\
\text { ports ponderosa pine better } \\
\text { than Belle Fourche and } \\
\text { Skull Creek. Sandstone } \\
\text { most common in upper half. } \\
\text { About } 50 \mathrm{ft} \text { up from base } \\
\text { is fossiliferous sandy mark- } \\
\text { er zone (see text). Fish } \\
\text { scales abundant through- } \\
\text { out. }\end{array}$ \\
\hline $\begin{array}{l}\text { Scattered pods and thin } \\
\text { discontinuous beds of } \\
\text { brown, fine- to me- } \\
\text { dium-grained sand- } \\
\text { stone. Locally cross- } \\
\text { bedded. Some glau- } \\
\text { conite and partings of } \\
\text { siltstone and mud- } \\
\text { stone. }\end{array}$ & $\underset{10}{\text { Range, } 0 \text { to }}$ & $\begin{array}{l}\text { Poorly exposed. See } \\
\text { Orace (1952). }\end{array}$ & & $\begin{array}{l}\text { Scattered exposures on the } \\
\text { west side of the valley of } \\
\text { Line Creek from area of } \\
\text { Wyoming Hill to the Dew- } \\
\text { ey fault. Small outcrops } \\
\text { as a thin ledge on the hills } \\
\text { along road in sec. } 15, T \text {. } 41 \\
N \text {., R. } 60 \text { W. about } 1 \text { mile } \\
\text { west of Dewey. }\end{array}$ \\
\hline $\begin{array}{l}\text { Dark-gray to black soft } \\
\text { flaky shale with inter- } \\
\text { bedded sandstones } \\
\text { and siltstones, espe- } \\
\text { cially near the top } \\
\text { and bottom. Wea- } \\
\text { thers black. Calcare- } \\
\text { ous cone-in-cone con- } \\
\text { cretions abundant } \\
\text { near the top. }\end{array}$ & $\begin{array}{l}\text { 250, esti- } \\
\text { mated }\end{array}$ & $\begin{array}{l}\text { Upper contact poorly } \\
\text { exposed. Lower } \\
\text { contact gradational } \\
\text { to Fall River forma- } \\
\text { tion (see below and } \\
\text { text). }\end{array}$ & & $\begin{array}{l}\text { Not well exposed because of } \\
\text { alluvial cover. Sandstone } \\
\text { dikes in upper } 50 \mathrm{ft} \text { (see } \\
\text { text). Some fish scales } \\
\text { found. Crystals of second- } \\
\text { ary selenite (gypsum) com- } \\
\text { mon. Where Newcastle } \\
\text { sandstone is absent, Skull } \\
\text { Creek in gradational con- } \\
\text { contact with Mowry. }\end{array}$ \\
\hline $\begin{array}{l}\text { Upper unit: Interlay- } \\
\text { ered mudstones and } \\
\text { carbonaceous fine- } \\
\text { grained to very fine } \\
\text { grained sandstones. } \\
\text { Middle unit: Sandstone } \\
\text { (Ss). } \\
\text { Lower unit: Gray to } \\
\text { black laminated car- } \\
\text { bonaceous siltstones } \\
\text { with some thin inter- } \\
\text { beded sandstones. }\end{array}$ & 125 , average & $\begin{array}{l}\text { Upper unit grades, } \\
\text { upward to Skull } \\
\text { Creek shale through } \\
\text { a zone } 5 \mathrm{ft} \text { thick in } \\
\text { which black shales } \\
\text { become more abund- } \\
\text { ant upward. Base } \\
\text { is unconformity. } \\
\text { See text. }\end{array}$ & $3,4,6,7$ & $\begin{array}{l}\text { Exposed in Elk Mountains. } \\
\text { See text for details. }\end{array}$ \\
\hline $\begin{array}{l}\text { S }_{4} \text { sandstone: Varicol- } \\
\text { ored m uds tones, } \\
\text { white to yellow sand- } \\
\text { stones, some con- } \\
\text { glomeratic. S S and } S_{4} \\
\text { sandstones: Conglom- } \\
\text { eratic. See text. }\end{array}$ & 200 , average & Disconformity at base. & $3,4,5$ & Do. \\
\hline $\begin{array}{l}\text { S s sandstone: In south } \\
\text { end of Elk Mountains } \\
\text { only; carbonaceous } \\
\text { mudstone. See text. }\end{array}$ & 25 , average & Base poorly exposed. & & \\
\hline
\end{tabular}


TABLE 1.-Stratigraphy of the western Black Hills

\begin{tabular}{|c|c|c|c|c|}
\hline \multirow{2}{*}{ Series } & \multirow{2}{*}{$\begin{array}{l}\text { Formation and } \\
\text { member }\end{array}$} & \multicolumn{3}{|c|}{ Western Black Hills } \\
\hline & & Lithology & Thickness (feet) & Remarks \\
\hline \multirow{6}{*}{ 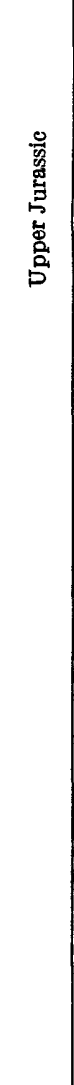 } & $\begin{array}{l}\text { Morrison forma- } \\
\text { tion }\end{array}$ & $\begin{array}{l}\text { Mostly gray, green, and } \\
\text { purple mudstones and } \\
\text { shales, some calcare- } \\
\text { ous, with some lime- } \\
\text { stone. }\end{array}$ & 100 average & $\begin{array}{l}\text { Beulah shale of Darton } \\
\text { (1901a). } \\
\text { Term brought to Black } \\
\text { Hills (Darton 1901b). } \\
\text { Age and correlation: } \\
\text { Reeside (in Yen, } \\
\text { 1952, p. 22-26). } \\
\text { Continental origin: Yen } \\
\text { (1952). }\end{array}$ \\
\hline & $\begin{array}{l}\text { Sundance forma- } \\
\text { tion }\end{array}$ & $\begin{array}{l}\text { Mostly gray and green } \\
\text { shale, silty sandstone, } \\
\text { and sandstone with } \\
\text { thin beds of limestone. } \\
\text { Some red beds. }\end{array}$ & 475 maximum & $\begin{array}{l}\text { Definition: Darton (1899, } \\
\text { p. 387-393). } \\
\text { Divided and described: } \\
\text { Imlay (1947). } \\
\text { Described and corre- } \\
\text { lated: Peterson (1954). } \\
\text { Marine and terrestrial } \\
\text { (?) origin. }\end{array}$ \\
\hline & $\begin{array}{l}\text { Redwater } \\
\text { shale mem- } \\
\text { ber }\end{array}$ & $\begin{array}{l}\text { Green shales and light- } \\
\text { gray sandstones. }\end{array}$ & Range, 80 to 190 & Marine origin. \\
\hline & Lak member & $\begin{array}{l}\text { Red siltstone and sand- } \\
\text { stone. }\end{array}$ & Range, 40 to 80 & $\begin{array}{l}\text { Terrestrial(?) origin. No } \\
\text { fossils found. }\end{array}$ \\
\hline & $\begin{array}{l}\text { Hulett sand- } \\
\text { stone mem- } \\
\text { ber }\end{array}$ & $\begin{array}{l}\text { Gray to yellow sand- } \\
\text { stone. Ripple marks } \\
\text { common. }\end{array}$ & Range, 40 to 75 & Marine origin. \\
\hline & $\begin{array}{l}\text { Stockade Bea- } \\
\text { ver shale mem- } \\
\text { ber }\end{array}$ & Principally green shale. & Range, 50 to 80 & Marine origin. \\
\hline 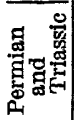 & Spearfish formation & $\begin{array}{l}\text { Red claystone, siltstone, } \\
\text { and sandstone with } \\
\text { some gypsum, anhy- } \\
\text { drite, and dolomite. }\end{array}$ & Range, 450 to 600 & $\begin{array}{c}\text { Definition: Darton (1899, } \\
\text { p. 387). Nonmarine. }\end{array}$ \\
\hline
\end{tabular}


and the Dewey quadrangle, Wyoming-South Dakota-Continued

\begin{tabular}{|c|c|c|c|c|}
\hline \multicolumn{5}{|c|}{ Dewey quadrangle } \\
\hline Lithology & $\begin{array}{c}\text { Thickness } \\
\text { (feet) }\end{array}$ & Contact & $\begin{array}{l}\text { Measured } \\
\text { section } \\
\text { No. }\end{array}$ & Remarks \\
\hline $\begin{array}{l}\text { Mostly gray, green, and } \\
\text { purple mudstones and } \\
\text { shales; some calcare- } \\
\text { ous mudstones in lower } \\
\text { part; discontinuous } \\
\text { beds and pods of sub- } \\
\text { lith ographic gray } \\
\text { limestone especially } \\
\text { in lower half. }\end{array}$ & $\begin{array}{l}\text { 100, a verage. } \\
\text { Absent in } \\
\text { sec 17, T. } \\
5 \mathrm{~S} . \text { R. i } \\
\text { E., Custer } \\
\text { County, } \\
\text { S. Dak. }\end{array}$ & $\begin{array}{l}\text { Upper contact poorly } \\
\text { exposed, appears to } \\
\text { be an unconformity. }\end{array}$ & 2 & $\begin{array}{l}\text { Exposures chiefly on east face } \\
\text { of Elk Mountains. Best } \\
\text { exposure SW1/4 sec. 16, T. } \\
5 \text { S., R. 1 E., Custer } \\
\text { County, S. Dak. Good } \\
\text { exposure NW1/4 sec. 28.T. } \\
5 \text { S., R. 1 E., Custer } \\
\text { County, S. Dak. Unit is } \\
\text { generally covered. }\end{array}$ \\
\hline $\begin{array}{l}\text { Mostly gray and green } \\
\text { shale, silty sandstone } \\
\text { with thin beds of } \\
\text { limestone. Some red } \\
\text { beds. }\end{array}$ & About 320 & $\begin{array}{l}\text { Upper contact is top } \\
\text { of } 15 \text {-feet bed of cal- } \\
\text { careous sandstone } \\
\text { with green silty } \\
\text { partings, weathers } \\
\text { yellow and forms } \\
\text { ledge. Base is un- } \\
\text { conformity. }\end{array}$ & & $\begin{array}{l}\text { Has } 5 \text { members, but only } 4 \\
\text { exposed here, The lowest } \\
\text { mem ber, the Can y on } \\
\text { Springs sandstone, is ab- } \\
\text { sent in Dewey quadrangle. }\end{array}$ \\
\hline $\begin{array}{l}\text { Gray to green shale, } \\
\text { some light-gray sand- } \\
\text { stone and sandy oolit- } \\
\text { ic and fossiliferous } \\
\text { limestone. Fine- } \\
\text { grained sandstones } \\
\text { with calcareous lami- } \\
\text { nae. Glauconite } \\
\text { abundant, most com- } \\
\text { mon near base. }\end{array}$ & 150 , average & $\begin{array}{l}\text { Top of member is top } \\
\text { of } 15 \text {-ft bed of calcar- } \\
\text { eous sandstone with } \\
\text { green silty partings. } \\
\text { Weathers yellow and } \\
\text { forms ledge. }\end{array}$ & 2 & $\begin{array}{l}\text { Best exposures on east face of } \\
\text { Elk Mountains in sec. } 16, \\
\text { T. } 5 \text { S., R. } 1 \text { E., Custer } \\
\text { County, S. Dak.; also sec. } \\
\text { 28, T. 5'S., R. } 1 \text { E. }\end{array}$ \\
\hline $\begin{array}{l}\text { Red siltstone and poorly } \\
\text { cemented sandstone. } \\
\text { About } 15 \mathrm{ft} \text { from top } \\
\text { is } 5 \mathrm{ft} \text { gray to green } \\
\text { sandy siltstone. }\end{array}$ & 70 , average & $\begin{array}{l}\text { Upper contact gener- } \\
\text { ally poorly exposed. } \\
\text { Change in color of } \\
\text { rocks from red of } \\
\text { Lak to green of Red- } \\
\text { water shale. }\end{array}$ & & $\begin{array}{l}\text { Forms covered slopes above } \\
\text { cliffs of Hulett sandstone. } \\
\text { Environment of deposition } \\
\text { not well understood. Lack } \\
\text { of marine fossils suggests } \\
\text { terrestrial(?) origin. }\end{array}$ \\
\hline $\begin{array}{l}\text { Chiefly fine-grained } \\
\text { gray to yellow sand- } \\
\text { stone firmly cement- } \\
\text { ed by calcite. Lower } \\
10 \text { ft has green shale } \\
\text { partings that increase } \\
\text { in abundance down- } \\
\text { ward. }\end{array}$ & 50 , average & $\begin{array}{l}\text { Upper contact: } \\
\text { Change upward } \\
\text { from gray to yellow } \\
\text { sandstone below to } \\
\text { red rocks of Lak. }\end{array}$ & & $\begin{array}{l}\text { Commonly forms ledges be- } \\
\text { tween covered slopes of } \\
\text { rocks above and below. }\end{array}$ \\
\hline $\begin{array}{l}\text { Dark-green fissile shale. } \\
\text { Some calcareous with } \\
\text { thin beds andlaminae } \\
\text { of fine-grained light- } \\
\text { gray sandstone and } \\
\text { siltstone, especially } \\
\text { in uppermost and } \\
\text { low erm ost parts. } \\
\text { Basal } 3 \text { to } 10 \text { ft is } \\
\text { whitelimy friable fos- } \\
\text { siliferous sandstone } \\
\text { with thin partings of } \\
\text { silt andlimy clay and } \\
\text { scattered rounded } \\
\text { polished rock frag- } \\
\text { ments as large as } 1 \text { in. } \\
\text { across. }\end{array}$ & 50, average & $\begin{array}{l}\text { Grades upward to } \\
\text { Hulett sandstone. } \\
\text { Contact placed in } \\
\text { zone where sand- } \\
\text { stone predominates } \\
\text { over green shale. } \\
\text { Base is unconform- } \\
\text { ity. }\end{array}$ & & $\begin{array}{l}\text { Exposed along east face of } \\
\text { Elk Mountains. The oys- } \\
\text { ter Ostrea stringilecula and } \\
\text { the pecten Camptonectes } \\
\text { sp. form a coquinoid sand- } \\
\text { stone as much as } 2 \text { ft thick } \\
\text { within } 3 \text { to } 10 \text { ft of the base. } \\
\text { Fossils identified by W. A. } \\
\text { Cobban. }\end{array}$ \\
\hline $\begin{array}{l}\text { Red siltstone and sand- } \\
\text { stone. Crossbeds in } \\
\text { sandstone, veins of } \\
\text { secondary gypsum. }\end{array}$ & $43+$ & $\begin{array}{l}\text { Unconformity at up- } \\
\text { per contact, where } \\
\text { upper } 1 \text { in. is } \\
\text { bleached white. } \\
\text { Base not exposed. }\end{array}$ & 1 & $\begin{array}{l}\text { Exposed in northeast corner } \\
\text { of quadrangle. Amount of } \\
\text { relief on the unconformity } \\
\text { in this area is unknown. }\end{array}$ \\
\hline
\end{tabular}




\section{PERMIAN AND TRIASSIC SYSTEMS}

\section{SPEARFISH FORMATION}

The regional and local characteristics of the Spearfish formation are summarized in table 1.

The Spearfish formation is exposed only in the northeast corner of the quadrangle. The upper 43 feet of the formation consisting chiefly of red siltstone and sandstone of Triassic age is well exposed near the Cornelison ranch house in the SE1/4SE1/4 sec. 8, T. 5 S., R. 1 E.

\section{Section of upper part of Spearfish formation}

Stockade Beaver shale.

Spearfish formation:

6. Sandstone, red, medium-grained. Uppermost Feet inches inch bleached white._._._-_._. 4

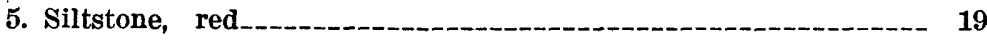

4. Sandstone, red, medium-grained, crossbedded

3. Siltstone, sandy, red._._._._. 54

2. Sandstone, red, crossbedded; with 4 silty layers 3 in. thick

1. Siltstone, red, with thin red sandstones in upper foot

\section{JURASSIC SYSTEM}

\section{UPPER JURA SSIC SERIES}

SUNDANCE FORMATION

The Sundance formation of Late Jurassic age consists of green shale, yellow-green and red fine-grained sandstone, silty sandstone, and some thin beds of gray limestone. Imlay (1947, p. 232-234) divided the formation into 5 members totaling a maximum stratigraphic thickness of 475 feet. The members from oldest to youngest are the Canyon Springs sandstone, the Stockade Beaver shale, the Hulett sandstone, the Lak, and the Redwater shale.

In the Dewey quadrangle the Sundance formation is about 320 feet thick. Exposures are generally poor and are limited chiefly to the lower slopes of the east face of the Elk Mountains. The Canyon Springs sandstone member is absent in this quadrangle. The regional and local characteristics of the Sundance are summarized in table 1.

\section{MORRISON FORMATION}

The Morrison formation was identified in the Black Hills by Darton (1901b), who previously had called these rocks the Beulah shale (Darton, 1901a). Reeside (in Yen, 1952, p. 22-26) and Yen (1952, p. 26) discussed in some detail the age and correlation of the Morrison in Wyoming and nearby areas. They concluded that the forma- 
tion is probably of Late Jurassic age. Regional and local characteristics of the Morrison formation are summarized in table 1.

The Morrison in the Dewey area consists principally of green to gray mudstones, although some beds are red to purple. The mudstones of the lower part of the unit are somewhat more calcareous than those of the upper part. Discontinuous beds and pods of finely crystalline to sublithographic gray limestone as thick as 1 to 2 feet are scattered throughout the unit, but occur most abundantly in the lower half. The limestone commonly contains blebs of calcite as much as one-fourth inch across. Lenses of gray, red, and black chert, a few inches thick and several feet long, occur chiefly in the upper half of the formation. Many of these are brecciated and recemented by silica. Small nodules of barite are scattered sparingly through the upper half of the unit.

Fossils were collected by W. J. Mapel in the SE1/4 sec. 33, T. 5 S., R. 1 E. (written communication, 1956). R. E. Peck identified the following charophytes: Echinochara spinosa Peck, Latochara latitruncata (Peck), and Actistochara bransoni Peck. The following ostracodes were identified by I. G. Sohn; "Metacypris" spp. and Darwinulasp.

In the Dewey quadrangle, the Morrison formation is exposed, although poorly, along the east face of the Elk Mountains. The slopes commonly are steep and grass covered or covered with talus and landslide debris. The best exposure is in the SW1/4 sec. 16, T. 5 S., R. 1 E., Custer County, S. Dak.; a measured section at this locality of the Morrison formation and the upper Redwater shale of the Sundance formation is given below :

2. Section of Morrison formation and part of the Redwater shale Lakota formation.

Morrison formation:

6. Mudstones, green to variegated. Feet inches

5. Limestone, gray, sublithographic; contains blebs of calcite one-fourth inch across._._._.-. 1

4. Mud, gray

3. Limestone, gray, lithographic_-_-_-_-_- 1

2. Mudstone, green

1. Limestone, yellow-brown._- 1

Morrison formation

Redwater shale member of Sundance formation (part) :

3. Sandstone, gray to yellow-brown, with green silty partings_-

2. Siltstone, olive-green, and silty mudstone

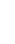

1

1. Mudstone, green-black

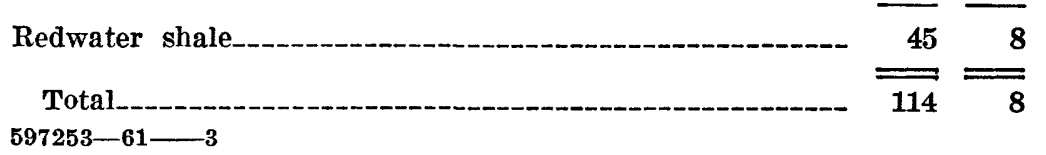


The unit ranges in thickness from 0 to 100 feet. The Morrison is about 100 feet thick in most of the quadrangle, but thins northward across a short distance in sec. 16 and the southern part of sec. 17, T. 5 S., R. 1 E. It is absent in north-central sec. 17 (pl. 5). It thickens again to the north, in sec. 8, T. 5 S., R. 1 E., in the Clifton quadrangle. The thinning probably was caused by erosion after local doming before the deposition of the overlying Lakota rocks.

The base of the Morrison formation is at the top of a gray to yellow calcareous sandstone with green silty partings that is the uppermost bed of the Redwater shale member of the Sundance formation. This sandstone apparently is widespread on the west side of the Black Hills and is an excellent contact marker.

The contact of the Morrison with the overlying Lakota formation is rarely exposed. In the $\mathrm{SW}^{1 / 4}$ sec. 16, T. $5 \mathrm{~S}$., R. $1 \mathrm{E}$., it is marked by a sharp change from the dark-brown carbonaceous siltstone of the Lakota to the green or variegated mudstones and claystones of the Morrison. Regional studies indicate that this contact is unconformable.

The depositional environment of the Morrison formation is construed to be terrestrial. The sediments possibly were deposited on a lake-studded lowland.

\section{CRETACEOUS SYSTEM}

\section{LOWER CRETACEOUS SERIES}

\section{INYAN KARA GROUP}

Rubey (1930, p. 5) applied the name Inyan Kara group to a sequence of interbedded sandstones, siltstones, and mudstones of terrestrial origin that included, in ascending order, the Lakota sandstone and Fuson shale, both of Darton (1901a) and the Fall River sandstone of Russell (1927, 1928). Rubey was unable to separate the Fuson shale from the Fall River sandstone in the northern Black Hills. Thus, Rubey proposed the term Inyan Kara group for all these terrestrial rocks in the northern Black Hills because he could not divide them in the manner of Darton and Russell in the southern Black Hills.

Recent detailed studies by the U.S. Geological Survey of the entire west flank of the Black Hills indicate that the Inyan Kara group can be divided into two major units, the Lakota formation and the Fall River formation. The regional stratigraphy of these units and the evolution of their nomenclature are described in detail by K. M. Waagé (1959). The redefined Lakota formation of Waagé includes the Lakota sandstone, Minnewaste limestone, and Fuson shale of Darton. The latter two units of Darton are now members of the Lakota formation. The Lakota sandstone of Darton in the southern 
Black Hills has been redefined by Post and Bell (1961) as the Chilson member of Waagés Lakota formation. The Fall River formation is a redefinition of the Fall River sandstone of Russell (1928).

In the Dewey quadrangle the group averages 350 feet thick (see stratigraphic section 3 ). The Lakota formation has an average thickness of 225 feet and includes rocks of the Chilson and Fuson members. (The Minnewaste limestone member which occurs between the Chilson and Fuson members in some areas of the southern Black Hills is absent in this quadrangle.) Rocks of the Chilson member include, from the base upward: (1) carbonaceous mudstone and some interlayered sandstone, and (2) white to brown $S_{1}$ sandstone which is limited to the southern end of the Elk Mountains. Rocks of the Fuson member include (1) massive to crossbedded white to brown $\mathrm{S}_{3}$ sandstone with abundant chert-pebble conglomerate, (2) varicolored mudstone and interbedded sandstone and siltstone, as well as some locally mappable sandstone, and (3) yellow to white $\mathbf{S}_{4}$ sandstone that is locally conglomeratic.

The Fall River formation has an average thickness of 125 feet and may be mapped as 3 units. From the base upward they are (1) carbonaceous siltstone and interbedded sandstone, (2) massive to crossbedded $\mathbf{S}_{5}$ sandstone, and (3) interbedded mudstone and carbonaceous sandstone.

3.-Generalized stratigraphy of the Inyan Kara group in the Dewey quadrangle, Wyoming-South Dakota

Fall River formation:

3. Upper unit: Interlayered mudstones and carbonaceous fine-grained to very fine grained sandstones.

Thicknes8, in feet

$\begin{array}{cc}\text { (feet) } & \begin{array}{c}\text { Average } \\ \text { (feet) }\end{array} \\ 60-80 & 75\end{array}$

2. Middle unit: $S_{5}$ sandstone, yellow to red-brown, medium-grained, quartzose, massive to crossbedded

1. Lower unit: Gray to black laminated carbonaceous siltstone and thin beds of sandstone.

$0-40$

Total Fall River formation

\footnotetext{
1 The numbers here assigned to the sandstones are the same as the numbers assigned to equivalent sandstones mapped in other quadrangles in the southern Black Hills during the course of uranium studies by the U.S. Geological Survey in this area. Six major sandstone units have been mapped. The subscript numbers 1 to 6 indicate decreasing age. Sandstones $S_{2}$ and $S_{6}$ are absent in the Dewey quadrangle.
} 
Lakota formation:

Fuson member:

3. $\mathbf{S}_{4}$ sandstone, yellow to white, locally conglomeratic

Thicknes8, in feet

Range Average

(feet) (feet)

2. Mudstone, interbedded with siltstone and sandstone. Some locally mappable sandstone.

$20-200+130$

1. $\mathbb{S}_{3}$ sandstone, crossbedded, white to brown, abundant chert-pebble conglomerate

$0-100+50$

Total Fuson member

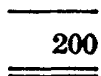

Chilson member:

2. $\mathbb{S}_{1}$ sandstone, white to yellow and brown at south end of Elk Mountains only. No $S_{3}$ over it; thickness of $S_{1}$ and $S_{3}$ are compensating

$0-60$

1. Mudstone, brown, gray to black earbonaceous, with some interlayered sandstone

$0-50$

Total Chilson member-1-.--

Total Lakota formation

Total Inyan Kara group

350

The most nearly complete and best exposed section of the rocks of the Inyan Kara group in the Dewey quadrangle is on the east face of the Elk Mountains about 3 miles northeast of Dewey, in the SE1/4SE1/4 sec. 33, T. 5 S., R. 1 E., Custer County, S. Dak. This section described below was measured by W. J. Mapel and modified by the author.

\section{Section of rocks of the Inyan Kara group}

Top of the ridge.

Fall River formation (part) :

Middle unit:

2. $S_{5}$ sandstone, yellowish-gray, weathers grayish-orange, mostly fine-grained becoming medium- to coarse-grained in the basal $2 \mathrm{ft}$, scattered clay pellets in the lower part; contains a few dark-brown weathering ferruginous concretions; forms a cliff

1. Covered. (Lower unit of Fall River and contact between the Fall River and Lakota formations in this interval)-.-- 5

Total Fall River formation 
Lakota formation (part) :

Fuson member:

13. $S_{4}$ sandstone, light-gray, mottled jellow and pink locally, mostly fine- to very fine grained, scattered coarse grains and granules in the upper half; clayey, very friable

12. Sandstone, light-gray to yellowish-gray weathers pale orange, fine-grained; mostly in beds 3 to $5 \mathrm{ft}$ thick; indistinctly crossbedded ; forms ledges.

11. Partly covered; appears to be mostly light-gray clayey siltstone; weathers grayish red at the top; nonresistant

10. Siltstone, in alternating light-gray and dusky-red bands; nonresistant

9. Covered

8. Sandstone, light-gray to yellowish-gray, fine-grained, firmly cemented; contains a few nodules cemented with iron oxide

7. Siltstone, medium-gray, clayey

6. Sandstone, very light gray, very fine grained, firmly cemented_

5. Siltstone, medium-gray, clayey becoming more clayey at the top; some interbedded very fine grained light-gray sandstone; nonresistant

4. Sandstone, very light gray, very fine grained, in beds 2 in to 3 ft thick, crossbedded, firmly cemented; contains a few scattered ferruginous sandstone nodules_....................-

3. Covered

2. Claystone, dark-gray, sandy, nonresistant_._.

1. $\mathrm{S}_{\mathbf{z}}$ sandstone, light-gray, fine- to coarse-grained and lenses and stringers of granulite and pebble conglomerate; larger fragments mostly chert and quartzite in lower $15 \mathrm{ft}$. From 15 to $30 \mathrm{ft}$ above base are scattered nodules and discontinuous layers of sandstone cemented by iron oxide. Upper $25 \mathrm{ft}$ is light gray to yellow, fine grained, friable. Massive at base, become indistinctly bedded toward top. Forms cliff--

Total Lakota formation

Lakota and Morrison formations, undivided :

1. Covered. Chilson member of Lakota and contact of Morrison and Lakota formations in this interval

Morrison formation:

1. Claystone, greenish-gray with purple bands, calcareous; contains few thin beds of nodular argillaceous limestone___._- 11

Several characteristics make it possible to distinguish the rocks of the Lakota from those of the Fall River. The rocks of the Fall River commonly contain accessory muscovite in amounts visible to the un- 
aided eye, but field and laboratory studies indicate that mica is very rare in the Lakota. Sandstones in the Fall River generally weather to yellow or red brown, are well sorted, and rarely contain chert. Sandstones in the Lakota generally weather to gray or yellow and generally are poorly sorted, especially in the coarser sizes. Chert conglomerate is common in the $\mathrm{S}_{3}$ sandstone of the Lakota and occurs at scattered places in many sandstones of the upper unit. The Lakota sandstones commonly contain what appear to be grains of aggregated yellow clay about the same size as the other grains in the rock These grains give a characteristic spotted appearance to the rock. Thin section studies reveal that these grains are chiefly weathered chert, although some could be altered feldspar. Lastly, the finegrained rocks of the Fall River are generally thinner bedded and more laminated than those of the Lakota.

The marked contrast between the characteristics of the Fall River and the Lakota formations suggests that the twofold division of the group is reasonable. The differences in the character of the bedding and mineralogy of the two formations indicate changes in conditions of deposition and perhaps a change in source area or at least a change in the kind of source material. This will be discussed further in the sections on each formation.

\section{Chilson member}

LAKOTA FORMATION

The Chilson member of the Lakota formation in the Dewey quadrangle consists of two units of rock-a basal carbonaceous brown, gray to black mudstone and siltstone with some interlayered sandstones and the white to yellow and brown $\mathrm{S}_{1}$ sandstone. (See pl. 5.)

The basal mudstone unit is as much as 50 feet thick, but probably averages 25 feet. The exposures of this unit are few and generally poor and are restricted to the east face of the Elk Mountains and to the deeper cut valleys on the dip slope that are nearest the east side of the mountains. The best exposure is on the east face of the Elk Mountains in the SW $1 / 4$ sec. 16 , T. 5 S., R. 1 E. A measured section of the Lakota formation at this locality is given below. 


\section{Section of Lakota formation}

Top of ridge.

Lakota formation (part) :

Fuson member:

Feet Inches

1. $S_{3}$ sandstone, yellow-brown, massive to crossbedded with cherty conglomerate.

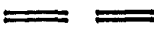

Chilson member :

7. Mudstone, red

6. Mudstone, yellow

5. Mudstone, gray

4. Sandstone, gray to yellow, medium- to course-grained--

3. Covered

2. Sandstone, fine-grained, white; contains ferruginous concretions

1. Shale, dark-brown, fissile and siltstone with abundant carbonaceous matter

Chilson member

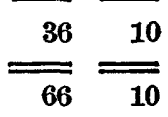

Morrison formation.

The next best exposures of the basal mudstone unit are on the walls of the valley west of Sullivan Peak, $11 / 2$ to 2 miles south of the exposures described above. On the north wall of the valley the unit consists of about 20 feet of gray siltstone exposed below the overlying $S_{3}$ sandstone unit. The exposures on the south wall of the valley are in the cut of an access road. Here the unit is about 50 feet thick; from the top downward it consists of 10 feet of gray silty mudstone, 5 feet of white, fine-grained sandstone, 30 feet of gray carbonaceous silty mudstone, 1 foot of black carbonaceous mudstone, and 4 feet of gray siltstone lying on the Morrison formation.

The great variation in the thickness of this unit from place to place probably is the result of channeling before deposition of the overlying $\mathrm{S}_{1}$ and $\mathrm{S}_{3}$ sandstones. In the northeastern part of the Dewey quadrangle, particularly in sec. 17, T. 5 S., R. 1 E., the unit is absent and the overlying conglomeratic $\mathbf{S}_{3}$ sandstone rests on the Morrison for- 
mation, if present, or the Redwater member of the Sundance formation. The 4 localities described above show the variations in the unit across a distance of nearly 2 miles.

The fine-grained nature of most of the rocks in this unit, together with the abundant carbonaceous matter, especially in the lower part, is suggestive that these rocks were deposited on swampy plains and probably in areas between river channels.

The $\mathrm{S}_{1}$ sandstone is widely distributed on the southern and western flanks of the Black Hills. It has been mapped continuously from the south end of the Elk Mountains to the vicinity of Hot Springs, S. Dak., a distance of about 50 airline miles. To the north the $\mathbf{S}_{1}$ sandstone is again exposed in the northern part of the Clifton quadrangle, along the west side of the Fanny Peak quadrangle, and beyond to the northwest flank of the Black Hills.

In the Dewey quadrangle, the $S_{1}$ sandstone crops out only on 60foot cliffs on the east face of the Elk Mountains at their southeast end. The best exposures are on spurs that extend southeastward into the adjacent Jewel Cave SW quadrangle where the $S_{1}$ sandstone forms cliffs that are 100 to 120 feet high. The $S_{1}$ sandstone is not exposed in the Dewey quadrangle north of the $\mathrm{SE} 1 / 4$ sec. 4 , T. 6 S., R. 1 E. Somewhere between this exposure and another about 1 mile to the north in the SE1/4 sec. 33, T. 5 S., R. 1 E., the $\mathrm{S}_{1}$ sandstone pinches out, probably by truncation by the $\mathrm{S}_{3}$ sandstone.

The $\mathbf{S}_{1}$ sandstone is generally yellow to red brown and consists of 90 to 95 persent quartz of very fine to coarse grain loosely cemented by interstitial clay.

The contact of the $S_{1}$ sandstone with the underlying rocks of the Lakota is poorly exposed; it appears to be irregular, though the amount of relief on the contact surface is probably small. The upper contact of the $S_{1}$ sandstone with the $S_{3}$ sandstone is irregular and marked by channel scours and fillings of $S_{3}$ sandstone.

W. A. Braddock (written communication, 1956) reports that in the adjacent Jewel Cave SW quadrangle, the $S_{1}$ sandstone is a complex of anastomosing channel fillings that finger out laterally and are enclosed by mudstones. Individual channels can be traced on outcrops for a few hundred feet at most, beyond which they merge or are truncated by other channel fillings.

\section{Fuson member}

The Fuson member of the Lakota formation in the Dewey quadrangle consists of three major mappable units: (1) the $S_{3}$ sandstone; (2) varicolored mudstone interbedded with siltstones and sandstones; some of the latter are locally mappable; and (3) the $\mathrm{S}_{4}$ sandstone. 
The $\mathrm{S}_{3}$ sandstone is exposed from about 1 mile north of the Dewey fault in the Dewey quadrangle northward along the west flank of the Black Hills. The $\mathrm{S}_{3}$ sandstone forms cliffs 20 to 60 feet high on the east face of the Elk Mountains. North of Triangle Park, exposures of the $S_{3}$ sandstone are abundant not only on the east face of the mountains, but also westward down the dip slope and in the incised canyons nearly to the western foot of the mountains. In some of these canyons the sandstone forms cliffs 80 to 100 feet high, and the base of the sandstone is not exposed. Approximately 1 mile north of the Dewey quadrangle, in Kouba Canyon in the Clifton quadrangle, exposures of the entire $S_{3}$ sandstone attain a thickness of 120 feet.

The $\mathrm{S}_{3}$ sandstone is white to yellow to red brown. The texture varies greatly, even in a single outcrop. In one vertical exposure of 50 feet the unit may contain irregular beds or lenses of chert pebble conglomerate and granule to very fine grained sandstone. The rock is locally cemented by calcite. The boundaries between the texturally different parts may be either sharp or gradational, and sorting within different parts is generally good. Scour-and-fill structures are common; crossbedding is abundant. Locally the sandstone is poorly bedded and even has a massive appearance.

The unit is predominantly a quartzose sandstone in which quartz makes up more than 90 percent of the rock. The grains of quartz are frosted and rounded. The rounding index (Krumbein, 1941) is about 0.5 . Other constituents are traces of feldspar and yellow clayey grains that are altered chert or feldspar. Among the heavy accessory minerals are magnetite, zircon, and rutile. Thin films of secondary iron oxide coat the grains in some places.

Locally, the chert pebble conglomerate predominates, especially in outcrops in the northeastern part of the Dewey quadrangle, secs. 16, 17, and 20, T. 5 S., R. 1 E., Custer County, S. Dak. The well-rounded pebbles are white, gray, and black and are as much as one-half inch along the longest dimension, although the average is about one-fourth inch. The matrix is mixed sand and clay.

The contact of the $S_{3}$ sandstone with the underlying rocks appears to be irregular. Some part of the lower unit of the Lakota formation probably underlies the $S_{3}$ sandstone over most of the quadrangle. The $S_{3}$ sandstone lies on the Morrison formation where the lower unit of the Lakota is absent, as in sec. 17, T. 5 S., R. 1 E. 'The $\mathrm{S}_{3}$ sandstone lies directly over the Redwater shale member of the Sundance formation where the Morrison is absent as at places in sec. 17, T. 5, S., R. 1 E. (pl. 5). Where the $S_{3}$ sandstone lies on the Morrison or the Redwater, it is very conglomeratic and crossbedded.

$597253-61-\longrightarrow 4$ 
Although the $\mathrm{S}_{3}$ sandstone appears to merge gradationally with the less resistant overlying units, especially the unit of mudstone, the top of the $\mathrm{S}_{3}$ sandstone is generally marked by a distinct topographic break from steep clifis to less steep covered slopes. Structure contour lines on the top of the $\mathrm{S}_{3}$ sandstone are shown in figure 7 .

Geologic work in the Dewey, Clifton, and Fanny Peak quadrangles suggests that the $S_{3}$ sandstone is an elongate body of rock whose thickest and coarsest parts trend north or northeast. Exposures of the complete thickness of the thickest and coarsest parts of the body are better in the Clifton and Fanny Peak quadrangles than in the Dewey quadrangle. Insufficient data are available in the Dewey quadrangle to prepare a reliable isopach map of the $S_{3}$ sandstone.

The elongate shape of the thickest and coarsest parts of the unit, the great variation in grain size, the abundant crossbedding, and the unconformable contact with underlying rocks suggest that the body is a complex of sandstones and conglomerates which were deposited in a river-channel system. The crossbedding suggests that the direction of flow was northward to northeastward.

Yellow carnotite-type minerals were found in the lower 10 feet of the 30- to 40 -foot high cliff of the $\mathrm{S}_{3}$ sandstone in the $\mathrm{SE} 1 / 4 \mathrm{SW} 1 / 4$ sec. 21, T. 5 S., R. 1 E., Custer County, S. Dak. The uranium minerals are interstitial in generally medium-grained quartzose sandstones and form scattered patches and irregular streaks a few inches long on the face of the cliff. The sandstone is light yellow to pink and red brown. The cliffs in this vicinity have been prospected, but no minable deposits of uranium have been found.

The mudstone unit of the Fuson member is a heterogeneous sequence of rocks composed principally of varicolored mudstones, gray siltstones, and some white to yellow sandstones-some locally conglomeratic. The unit ranges in thickness from less than 100 to more than 200 feet.

This unit generally forms slopes covered by a thin mantle of soil that supports grass and juniper. 'The slopes are broken by scattered outcrops of resistant sandy beds, which form thin ledges or cliffs a few feet to 20 feet thick. Nowhere is the complete section well exposed in one outcrop.

Mudstone is the most abundant rock type in the unit. Individual beds are chiefly gray, yellow, green, or red, although a few are mottled. Discontinuous thin laminae of sand are common. The mudstones of the upper part of the unit are commonly red and green; those in the lower part are chiefly gray and yellow. Many of the mudstones are carbonaceous, especially in the lower parts of the unit. Clayey and sandy siltstones also are abundant throughout this unit. Most of 


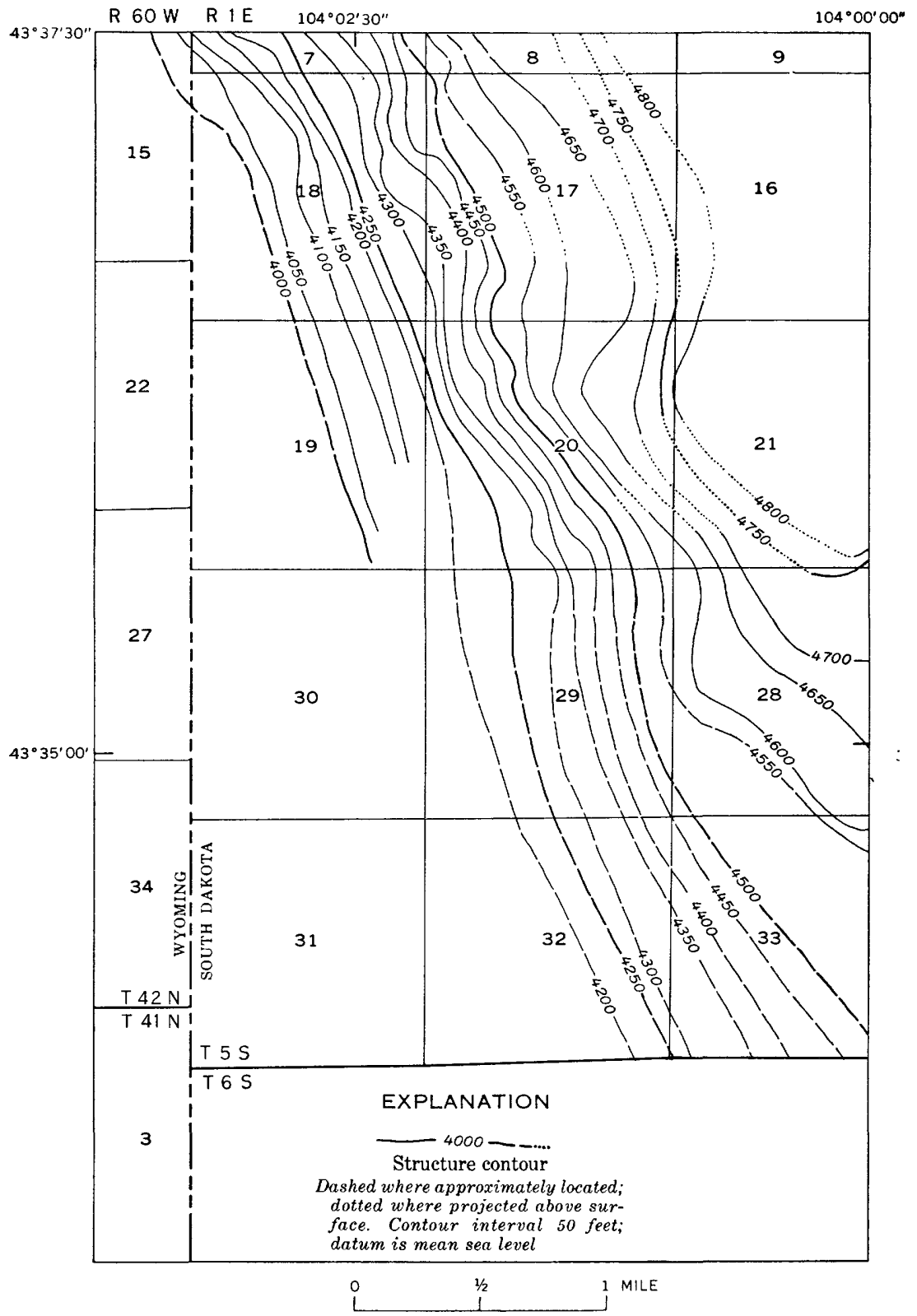

Figure 7.-Structure contour map of the top of the $S_{8}$ sandstone of the Fuson member of the Lakota formation in the northeastern part of the Dewey quadrangle, WyomingSouth Dakota. 
these are gray, but some are red to brown. Carbonaceous matter is common in these beds.

Very fine grained to medium-grained sandstones, which locally contain small amounts of conglomerate, are interbedded with the mudstones and siltstones. Some of these standstones are mappable locally and are shown on plate 5. These sandstones are white to yellow, but some are dark brown, green, or pink. Most of them contain about 95 percent quartz and less than 5 percent feldspar and chert. The grains have a rounding index (Krumbein, 1941) of 0.5. Small amounts of carbonaceous matter are common. The heavy mineral assemblage includes zircon, tourmaline, rutile, staurolite, and hornblende. Zircon and tourmaline comprise more than 90 percent of the heavy minerals (W. J. Mapel, written communication, 1957).

Several beds of very fine grained quartzose sandstone are green because of interstitial green chlorite. A sample from one bed in the NE $1 / 4$ sec. 8, T. 6 S., R. 1 E., contained about 95 percent quartz and a few grains of chert, microcline, plagioclase, muscovite, and zircon and about 5 percent green chlorite and clay.

Most of the sandstones are loosely cemented by clay. In scattered places cement of silica or calcite makes the rocks more resistant to weathering.

The sorting in the beds of very fine grained to medium-grained sandstone generally is good. One exception, however, is a 5 -foot bed of yellow argillaceous sandstone in which rounded pebbles of quartz and chert half an inch in diameter are embedded in a mixture of clay, silt, and sand-sized grains of quartz and chert. The pebbles are scattered throughout the beds and make up about 5 percent of the total rock; the sand-sized grains constitute about 55 percent of the rock, and the clay and silt perhaps a little more than 40 percent.

The $\mathrm{S}_{4}$ sandstone is the uppermost unit of the Fuson member in the Dewey quadrangle. It is chiefly a yellow to gray medium-grained quartzose sandstone containing abundant lenses of conglomerate consisting of rounded pebbles of gray and brown chert and rounded aggregrates of quartz grains as large as one-fourth inch in diameter. The matrix of the conglomerate is sand and clay.

The texture varies greatly across short distances horizontally and vertically. The texturally different discontinuous beds and lenses have either gradational or sharp truncating contacts. Crossbedding is common throughout the unit. Orientation of the crossbeds suggests that the material was moving toward the northwest. Considering the entire unit, the sorting generally is poor, although in some beds and lenses, especially the nonconglomeratic ones, the sorting is better. All these features are well exposed on outcrops on the west wall of a small canyon in the NE $1 / 4$ sec. 8, T. 6 S., R. 1 E. 
This sandstone commonly forms cliffs 5 to 20 feet high and attains a known maximum thickness of 70 to 80 feet on the walls of Plum Canyon (SW1/4 sec. 32, T. 5 S., R. 1 E.). In the upper end of the canyon, the $S_{4}$ sandstone is overlain by the $S_{5}$ sandstone (the middle unit of the Fall River formation), and underlain by another sandstone (pl. 5) in the mudstone unit of the Fuson member. In the lower end of the canyon, the $\mathrm{S}_{4}$ sandstone is overlain by carbonaceous siltstone of the lower part of the Fall River formation and underlain by the same sandstone of the Lakota mentioned above. Irregular contacts between these sandstones can be seen on the canyon walls.

The many textural variations, the elongate nature of the thickest parts of the body, the variation in thickness, the crossbedding, and the truncating contacts of the whole body of rock as well as those within the body suggest that this conglomeratic sandstone was deposited in a system of river channels.

\section{Lower unit}

FALL RIVER FORMATION

The lowest unit of the Fall River formation is a sequence of gray to black laminated, carbonaceous siltstones (pl.5). The carbonaceous matter occurs in black laminae generally less than one-fourth inch thick. Some thin layers of sandstone as much as 3 inches thick are intercalated with the siltstones. Locally, this unit is a black silty shale, as seen at the west end of the valley near the center of sec. 29 , T. 5 S., R. 1 E.

The bedding and lamination of the siltstones are very irregular and discontinuous. Local shallow scouring and filling within this unit were common, and results of this action can be seen in many exposures.

The unit ranges in thickness from 0 to 40 feet; its average thickness is about 20 feet. The unit is thickest on the southern end of the Elk Mountains where it is exposed at many places in secs. 5 and 8, T. 6 S., R. $1 \mathrm{E}$. (pl. 5). The siltstones were removed locally by channeling before the deposition of the overlying $\mathrm{S}_{5}$ sandstone. Fragments of the randomly oriented siltstones can be found in the lower part of sandstone $S_{5}$ near the western foot of the Elk Mountains, particularly on the north wall of the canyon in $\mathrm{SW} 1 / 4 \mathrm{SE} 1 / 4$ sec. 19, T. $5 \mathrm{~S} .$, R. $1 \mathrm{E}$.

The contact of the lower unit with the underlying Lakota formation is a regional unconformity (Waagé, 1959) that is generally covered or poorly exposed in this quadrangle. Over large parts of the Dewey quadrangle, siltstones of the lower Fall River formation rest on the conglomeratic $\mathrm{S}_{4}$ sandstone that is the uppermost lithologic unit of the Lakcta. Where the conglomeratic sandstone is absent, siltstones of the Fall River overlie the mudstone unit of the Fuson member of the Lakota formation. (See pl. 5.) 
The composition and structure of the rocks in this unit suggest that these rocks possibly were deposited in a swampy environment, perhaps on a flood plain in areas between the river channels.

\section{Middle unit ( $S_{s}$ sandstone)}

The middle unit of the Fall River formation is a yellow to redbrown quartzose rock called the $\mathrm{S}_{5}$ sandstone. The sandstone has been traced for about 50 miles from the Fanny Peak quadrangle, north of Dewey, southeastward to the vicinity of Hot Springs, S. Dak.

In the Dewey quadrangle, the $S_{5}$ sandstone is exposed over about two-thirds of the Elk Mountains where it forms the caprock on the dip slope (pl. 5). In the canyons and on the east face of the Elk Mountains the sandstone forms prominent cliffs that range in height. from 5 to more than 80 feet. The average thickness is about 30 feet. The thicker parts of the sandstone are well exposed in the cliffs along the eastern side of secs. 5 and 8, T. 6 S., R. 1 E.; in Plum Canyon, sec. 5, T. 6 S., R. 1 E., and sec. 32 , T. 5 S., R. 1 E.; in the canyon in the NE $1 / 4$ sec. 30, T. 5 S., R. 1 E., all in Custer County, S. Dak; and in the Wicker-Baldwin prospect, NE $1 / 4$ sec. 16, T. 42 N., R. 60 W., Weston County, Wyo.

The $S_{5}$ sandstone is a coarse- to fine-grained rock in which facies of medium grain predominate. Most of the rock is probably more than 90 percent rounded grains of quartz and accessory amounts (less than 5 percent) of plagioclase, microcline, muscovite, and chert. Bits and masses of carbonaceous matter are scattered throughout the unit. Lenses of lignitic material a few inches to a fow feet thick and as much as 50 feet long are found in the sandstone in the Wicker-Baldwin prospect.

Most of the sandstone is friable, but, locally, it is cemented by calcite and secondary silica. Concretions of calcite-cemented sandstone in the form of spheres and oblate spheroids a few inches to 6 feet in diameter are common and widespread. The surface of the concretions turns brown when exposed to weathering, but the interior remains white. Calcite makes up as much as 30 percent of the concretion. Some of these concretions are well exposed in the WickerBaldwin prospect.

Scattered irregular fragments and pods of red clay, 2 to 3 inches thick and several feet in diameter, are common. Fragments of the underlying carbonaceous siltstones and mudstones as large as 1 foot across are found in the lower parts of the sandstone.

Yellow carnotite-type uranium minerals occur in small amounts throughout the $S_{5}$ sandstone. The uranium minerals occur interstitial to the quartz grains and are associated with pyrite and carbonaceous materials, as at the Wicker-Baldwin prospect. 
An isopach map of the $S_{5}$ sandstone (fig. 8) shows the thicker part of the unit as a belt that is elongate to the northwest. It appears. that the $S_{5}$ sandstone is thickest where the Fuson member of the Lakota is thinnest. The inverse relation of these thicknesses suggests. that channeling of rocks beneath the $\mathrm{S}_{5}$ sandstone also removed some of the Lakota formation. Channeling at the base of the $S_{5}$ sandstone can be seen on the walls of Plum Canyon (sec. 5, T. 6 S., R. 1 E., and sec. 32 , T. 5 S., R. 1 E.).

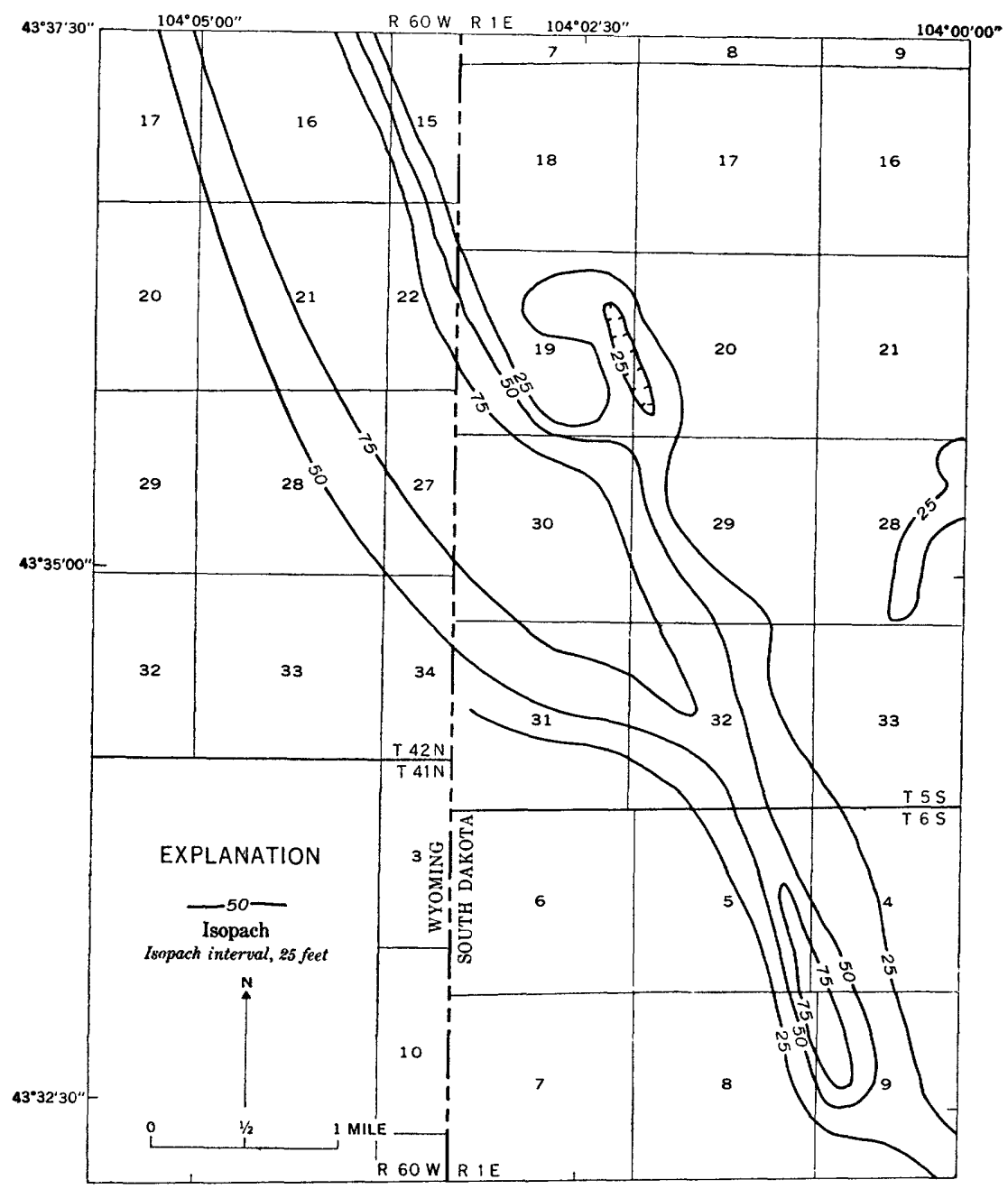

Frguan 8.- Isopach map of the $S_{5}$ sandstone in the Fall River formation in the northeastern part of the Dewey quadrangle, Wyoming-South Dakota. 
The sandstone thins toward the southwest and northeast from the thick elongate part. The thinning is abrupt, from more than 75 feet thick to only a few feet thick within a few hundred feet in many places. This can be seen in the canyons toward the west side of the Elk Mountains. East of the Wicker-Baldwin prospect, particularly in the NE1/4 sec. 16 , and the W1/2 sec. 15 , T. 42 N., R. 60 W., the $\mathrm{S}_{5}$ sandstone thins rapidly and appears to finger out in carbonaceous siltstone of the lower unit of the Fall River and in mudstones and thin sandstones of the upper unit. Cuttings from scattered exploratory drill holes west of the Wicker-Baldwin prospect indicate that the sandstone probably maintains a thickness greater than 60 feet for a distance of about 1 mile west of the prospect.

It is difficult to ascertain the relations of the $S_{5}$ sandstone to the enclosing rocks because of the generally poor exposures at the edges of the thicker parts of the $S_{5}$ sandstone and because of the similarity of lithology and structure of the $S_{5}$ sandstone to some of the sandstones of the enclosing rocks. Three possible stratigraphic relations of the $\mathrm{S}_{5}$ sandstone to the enclosing rocks are shown in cross section in figure 9. Figure $9 A$ shows the $\mathrm{S}_{5}$ sandstone as a group of channel fillings concentrated in one area. The individual channel fillings thin laterally to form sandstone beds interlayered with the enclosing rocks. Figure $9 B$ shows the $\mathrm{S}_{5}$ sandstone as one thick channel which thins laterally on each side to form two tongues that extend out into the enclosing rocks. Other sandstones in the enclosing rocks, though they may have characteristics similar to the $S_{5}$ sandstone, actually are truncated by the $\mathrm{S}_{5}$ sandstone.

In figure $9 C$ the channel filled by the $\mathrm{S}_{5}$ sandstone meandered across a plain cutting into the underlying rocks. Subsequently, this channel was filled and the stream wandered across an aggrading plain to produce lateral tongues of the channel filling interlayered with the enclosing rocks.

In the vicinity of the Wicker-Baldwin prospect the interlayering of the $\mathrm{S}_{5}$ sandstone with the enclosing rocks appears to be similar to that shown in figure $9 A$ or $C$. In other places the relations are as shown in figure $9 B$. It seems probable, therefore, that over the area of the $S_{5}$ sandstone, its relations with the enclosing rocks are combinations of those described above and shown in figure 9.

The relations of some of the sandstones in the upper unit of the Fall River to the $S_{5}$ sandstone are not clear because of poor exposures: Over its thicker parts, the $S_{5}$ sandstone appears to give way sharply to the interbedded mudstones and sandstones of the upper unit of the Fall River. 


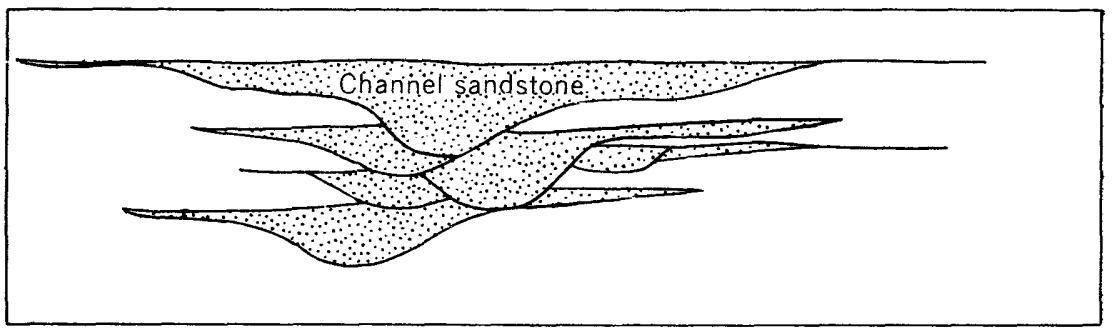

$A$

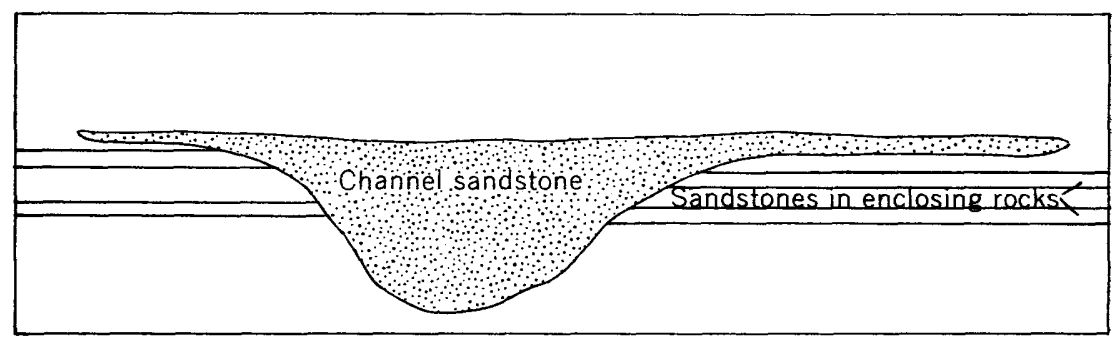

$B$
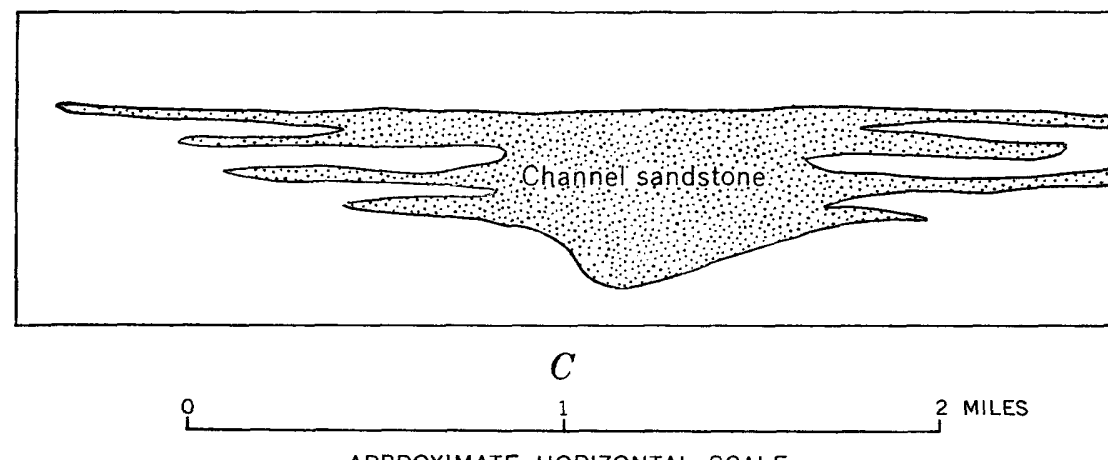

APPROXIMATE HORIZONTAL SCALE

VERTICAL DIMENSION GREATLY EXAGGERATED

FrguRm 9.- Schematic drawing of possible relations of complex channel sandstones to the enclosing rocks.

The distribution, thickness, and sedimentary structures of the $S_{5}$ sandstone and its contact relations with adjacent units suggest that it is a complex unit deposited in a fluviatile environment. The $\mathrm{S}^{5}$ sandstone commonly is crossbedded, and the dips of the crossbeds suggest a northward flow of the depositing complex of streams. 


\section{Upper unit}

The upper part of the Fall River formation is a complex lithologic unit consisting chiefly of interlayered mudstones and carbonaceous fine-grained to very fine grained sandstones. The unit is exposed only along the western foot of the Elk Mountains in a belt less than $1 / 4$ to about 1 mile wide (pl. 5). This sequence of rocks probably attains a maximum thickness of 80 feet, but the average thickness is estimated to be about 70 feet. The best exposures of the unit are in the vicinity of the Wicker-Baldwin prospect and in the $\mathrm{SW} 1 / 4$ sec. 5, T. 6 S., R. 1 E.; a measured section of this unit at that locality is described below.

\section{Section of upper part of Fall River formation}

Black shale of Skull Creek formation.

Feet inches

Upper unit of the Fall River formation :

15. Sandstone, brown, thin-bedded, crossbedded, carbonaceous, calcareous, quartzose

14. Mudstone, including some black shaly beds; poorly exposed.

13. Mudstones, poorly exposed

12. Sandstone, thin-bedded, crossbedded, very fine grained, carbonaceous, quartzose

11. Mudstone, gray to yellow, carbonaceous with sandy laminae

10. Mudstone, yellow to brown

9. Sandstone, brown to red, thin-bedded, very fine grained, carbonaceous, quartzose

8. Mudstone, gray to brown

7. Sandstone, yellow to pink, very fine grained, carbonaceous, quartzose

6. Mudstone

5. Sandstone, very fine grained, carbonaceous, quartzose

4. Mudstone, gray

3. Black shale

2. Mudstones, gray to varicolored.

1. Covered to top of $S_{5}$ sandstone

The sandstones are gray, yellow, brown, and red. Crossbedding is common. The individual beds range from 1 inch to several feet in thickness and most are discontinuous. Most of the sandstones are composed of more than 90 percent quartz which occurs as rounded frosty grains. Clay minerals and secondary iron oxides commonly fill the interstices. Associated minerals are clear muscovite in the form of disseminated flakes and carbonaceous matter. Small subhedral to euhedral crystals of clear gypsum, of secondary origin, are in both the sandstones and the mudstones. The sandstones are rarely calcareous, except in the upper parts of the unit. The brown calcar- 
eous sandstone described as the uppermost bed of the section above (unit 15) is believed to be within 5 feet of the top of the Fall River.

The mudstones are chiefly yellow or gray, but some are black or various shades of red. Carbonaceous matter is common as minute disseminated fragments or concentrated in laminae. Discontinuous laminae or pods of very fine quartzose sand and secondary iron oxides are also common. Small subhedral to euhedral crystals of clear gypsum are scattered throughout the mudstones.

The black mudstones are most abundant near the contact with the overlying black Skull Creek shale. The upper contact perhaps is gradational through a zone about 5 feet thick that is characterized by the gradual decrease in the abundance of sandstone beds and the gradual increase of black shale beds upward from the Fall River to the Skull Creek shale. The gradational zone between these units is not generally well exposed, but it may be seen in SW1/4 sec. 19 and SW $1 / 4$ sec. 30, T. 5 S., R. 1 E., and SW1/4 sec. 8, T. 6 S., R. 1 E. In mapping, however, unit 15 in the measured section above was considered the uppermost bed of the Fall River formation. This calcareous bed has been found from the Dewey quadrangle northward across the Clifton and Fanny Peak quadrangles.

Over the thicker parts of the $S_{5}$ sandstone, the contact with the upper unit of the Fall River formation is marked by an abrupt change from sandstone below to interlayered thin-bedded sandstone and mudstone above. The individual beds of the sequence of interlayered thin-bedded sandstones and mudstones vary in thickness laterally across short distances as seen in the area of the following section, measured on the north wall of the cut 100 feet west of the portal at the Wicker-Baldwin prospect ( $\mathrm{NE} 1 / 4$ sec. $16, T .42$ N., R. 60 W.).

\section{Alluvium.}

\section{Section of part of upper unit of Fall River formation}

Dpper unit of Fall River formation (part) :

Inches

16. Mudstone, gray-__- 2

15. Sandstone, brown, medium-grained____._._._- 4

14. Mudstone, gray

13. Sandstone, brown, medium-grained._._. 2

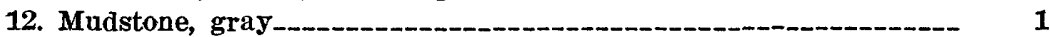

11. Sandstone, brown

10. Mudstone, gray

9. Sandstone, brown, muddy partings_________._- 1

8. Sandstone, brown n_._._. 3

7. Mudstone, gray, laminated.___.___._. 8

6. Sandstone, yellow-brown, medium-grained. Pinches out $1 \mathrm{ft}$ left of section and $20 \mathrm{ft}$ to right_._._._. 8

5. Mudstone, gray. Six inches to right, brown sandstone begins 5 in. above base. Six feet to right, sandstone is 1 in. thick 
7. Section of part of upper unit of Fall River formation-Continued Upper unit of Fall River formation (part)-Continued

4. Sandstone, brown

3. Mudstone, gray

2. Sandstone, brown, medium-grained. Seven feet to right, sandstone pinches out in mudstone._.

1. Mudstone, gray

Middle unit of Fall River formation $\mathbf{S}_{5}$ sandstone.

The interlayering of discontinuous beds of mudstone and sandstone suggests that the rocks of this unit also are chiefly of continental origin. The upper part of the unit, however, where black shaly beds appear, may have been deposited in a marine or marginal marine environment that was transitional to the marine environment in which the conformably overlying Skull Creek shale was deposited.

\section{SKUIT CREER SHAIE}

The Skull Creek shale is a dark-gray to black soft flaky shale with interbedded siltstone and sandstone, especially near the top and bottom. The regional and local characteristics are summarized in table 1. In the Dewey quadrangle the unit is estimated to be about 250 feet thick. It constitutes the surface bedrock in about 10 square miles along the eastern side of the Dewey terrace. Exposures generally are poor and in the valley of Line Creek the formation is covered by a thin mantle of alluvium.

Sandstone dikes are abundant near the top of the Skull Creek shale, especially in the upper 50 feet, and some extend up into the Mowry shale. Six dikes are shown on the geologic map (pl. 5) within an area of 1 square mile about 1 mile west of Dewey. A large dike in sec. 17, T. 42 N., R. 60 W., extends northward into the Clifton quadrangle. Some of the dikes are exposed for several hundred yards; most of the dikes are about 1 foot thick.

The dikes are composed of fine-grained silicified sandstone containing some glauconite. Cataclastic textures are common. The sharp contact of the dikes with the enclosing black shale is smoothed as if by vertical movement along the plane of contact.

The mode of emplacement and the source of the sand are in doubt. Russell (1927) in discussing the problems of the sandstone dikes concluded that they were probably related to marine parts of the Newcastle sandstone and to sandstone in the Mowry shale. The dikes are insufficiently exposed in the Dewey quadrangle to determine whether the sand was squeezed up from below or dropped into a fissure in the shale from above. The similarity of the sandstone in the dikes to the 
sandstone in the discontinuous lenses of the Newcastle sandstone in the Dewey area suggests that the two sandstones might be related. It is notable in the Dewey area that the Newcastle is thin or absent where the dikes are most common. The presence of glauconite suggests that the sands from which the dikes were derived were of marine origin.

The upper parts of the Skull Creek shale have abundant calcareous concretions with cone-in-cone structure. The concretions are as large as 2 feet in diameter and weather gray, yellow, or brown. Some of the concretions are fractured in a septarian fashion. The cracks are filled with calcite.

The relations of the cone-in-cone concretions, the sandstone dikes, and the abundant small faults in the rocks of the Dewey terrace are particularly well exposed in the walls of an irrigation ditch in the NE1/4 sec. 21, T. 41 N., R. 60 W. (fig. 10).

\section{NEWCASTLE SANDSTONE}

Regionally, the Newcastle sandstone consists of lenticular beds of sandstone with lesser amounts of siltstone, carbonaceous shale, coal, and bentonite between the Skull Creek and Mowry shale. In the Dewey quadrangle the formation is poorly exposed and consists chiefly of discontinuous pods and lenses of sandstone. The thickness rarely exceeds 5 feet; the maximum thickness is about 10 feet. Contact relations with the enclosing black shales are obscure. On plate 5, the formation has been included with the Skull Creek shale. The regional and local aspects of the Newcastle sandstone are summarized in table 1.

\section{MOWRY SHALE}

The Mowry shale is composed of dark-gray siliceous shale and thin beds of sandstone and bentonite. It weathers to a silvery gray that is easily distinguished from the black weathered shales of the enclosing Skull Creek shale below and Belle Fourche shale above. The regional and local characteristics are summarized in table 1.

About 50 feet up from the base of the Mowry is a particularly conspicuous sandy zone that is so well exposed on the Dewey terrace north of the Dewey fault that it is suitable for determining structure (pl. 5). The zone is marked by 2 fossiliferous siliceous sandstones each about 1 to 3 feet thick separated by as much as 3 feet of shale. The fossils consist of myriads of fragments of fish bones and scales. The sandstone beds are fine to very fine grained. Fresh exposures are gray to light yellow; weathered surfaces are gray or rusty brown.

Good easily accessible exposures are about 200 feet south of the road west of Dewey in SW $1 / 4$ SE1/4 sec. 9, T. 41 N., R. 60 W., and on 

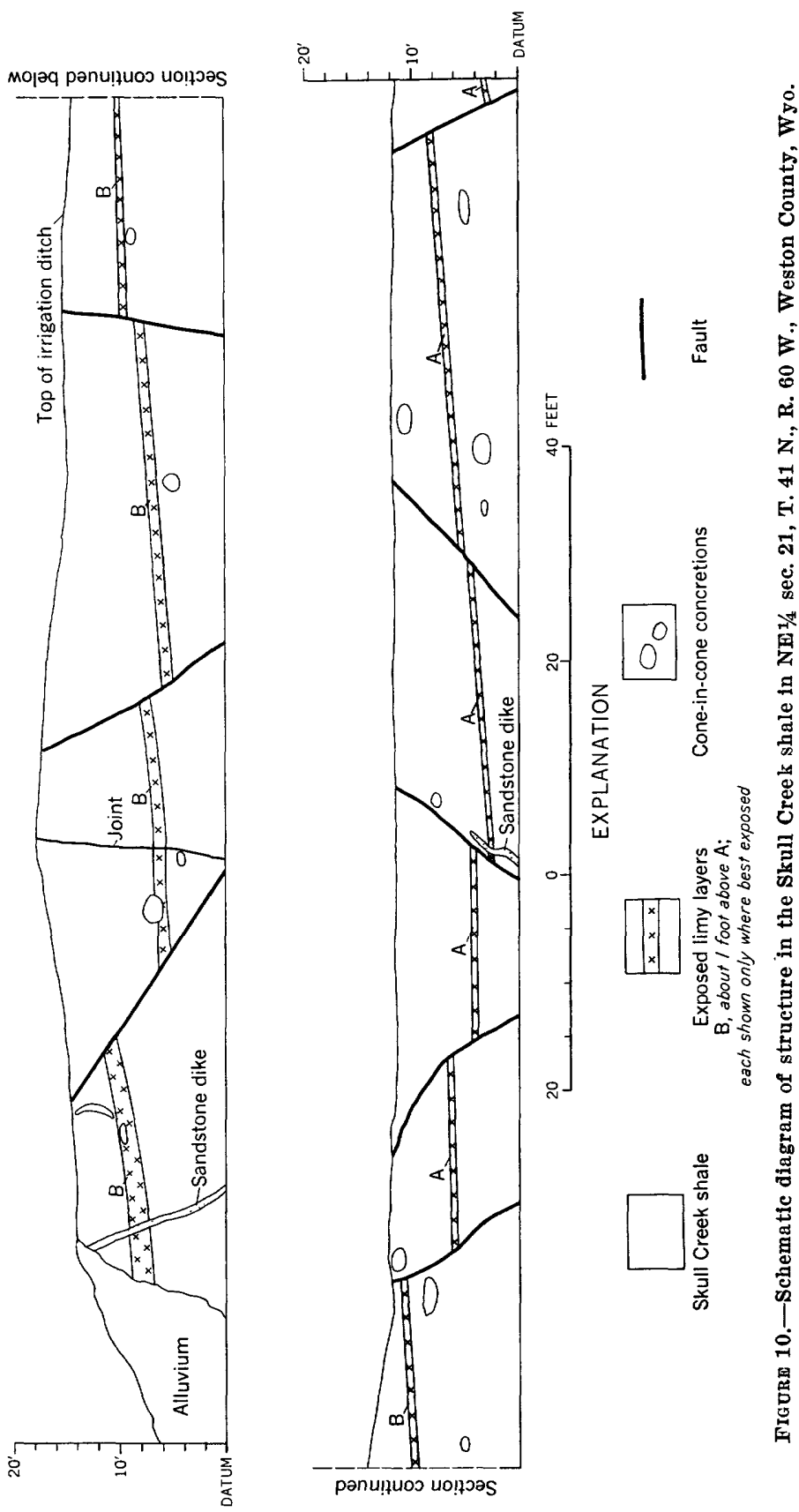
the cliff adjacent to Beaver Creek in the SW1/4NE1/4 sec. $18, T$. 41 N., R. $60 \mathrm{~W}$, and southward to the Dewey fault. The zone was not mapped south of the Dewey fault because of poor exposures.

The contact of the Mowry shale with the overlying Belle Fourche shale is marked by the Clay Spur bentonite bed. The bed is not more than 5 feet below a sharp color change from the silvery gray of the Mowry shale and the dull jet black so common in the Belle Fourche shale. The top of the Clay Spur bed has been considered as the contact between the two formations in the northern Black Hills (Robinson and others, written communication, 1961; Knechtel and Patterson, 1956). In some of the bentonite mines in the northern Black Hills, the Clay Spur bentonite bed is as much as 7 feet thick. In the Dewey quadrangle, several thin beds of bentonite occur in the vicinity of the color changes in the shales. The thickest of these bentonite beds is 1 to 2 feet thick and is within 5 feet of the color change. This bed is correlated with the Clay Spur bentonite bed and its top is considered the top of the Mowry shale. In the geologic mapping of the Dewey quadrangle, the cover and low dips of the Mowry shale on the Dewey terrace made it difficult to trace continuously any one of several bentonite beds. The color contact of the two shales, however, was followed as closely as possible. The contact between the two formations was plotted on the geologic map to coincide as closely as possible with the probable position of the Clay Spur bentonite bed.

\section{UPPER CRETACEOUS SFRIES}

\section{BEILE FOURCHE SHAIE}

The Belle Fourche shale is a gray to black shale with some beds of bentonite. The regional and local characteristics are summarized in table 1.

The Belle Fourche shale occupies the west side of the Dewey quadrangle (pl. 5). The formation is estimated to be about 400 feet thick, but only the lowermost 100 feet is well exposed.

The lower 40 to 50 feet of the Belle Fourche consists of soft black shales with intercalated thin beds of bentonite and several zones of scattered concretions and persistent thin layers of dark oligonite (iron-manganese carbonate). The oligonite weathers to a purple red. A thin layer of dark oligonite 1 to 6 inches thick is 15 to 20 feet above the base of the formation. This layer is overlain by about 6 inches of bentonite that weathers to a popcorn texture; the bentonite in turn is overlain by soft dull black shale. About 35 to 45 feet, but averaging 40 feet, above the base of the unit is a second layer of oligonite 1 to 6 inches thick, also overlain by a bentonite bed about 6 inches thick that weathers to a popcorn texture. The upper oligonite 
bed is exposed extensively north of the Dewey fault (pl. 5). The next 3 feet of black shale contain abundant discoid and kidney-shaped oligonite concretions. The discoids are as large as 5 feet in diameter and 6 to 8 inches thick. The kidney-shaped concretions have septarian cracks filled with yellow-brown calcite or siderite. The rock is chiefly black shale above the discoids and concretions.

The lower 100 feet of the Belle Fourche is particularly well exposed in the vicinity of the Lucky Strike bentonite prospect in secs. $19,20,29$, and 30 , T. 41 N., R. $60 \mathrm{~W}$.; on the small buttes in sec. 6 , T. 41 N., R. $60 \mathrm{~W}$.; and in the bentonite prospects $11 / 2$ miles southeast of M W Lake in secs. 20 and 30, T. 42 N., R. 60 W.

\section{GREENHORN FORMATION}

The Greenhorn formation in the Dewey quadrangle consists of gray to brown shales and gray to brown limestone with abundant Inoceramus labiatus. The formation is exposed only in a hogback in the northwest corner of the quadrangle. The regional and local characteristics are summarized in table 1.

\section{CARLILE SHALE}

The Carlile shale consists of three members. From oldest to youngest they are the lower unnamed member, the Turner sandy member, and the Sage Breaks shale member. The regional and local characteristics are summarized in table 1.

Only the lower unnamed member and the Turner sandy member are exposed in the Dewey quadrangle, where they form a small valley and a hogback west of the Greenhorn hogback in sec. 18, T. 42 N., R. $60 \mathrm{~W}$. A section measured at this locality follows.

Alluvium.

\section{Section of part of the Carlile shale}

Turner sandy member (part) :

Feet inches

2. Shale, black to gray, with sandy partings. Uppermost bed is 6 in. of gray to brown sandstone that forms dip slope of hogback

1. Sandstone, brown, calcareous, with shaly partings_._-_..--

Turner sandy member.

Lower unnamed member:

11. Shale, gray to black, with sandstone partings _-

10. Shale, gray to black -

9. Shale, gray to black, sand, and some gypsum

8. Shale, black, with bentonite and gypsum

7. Concretions, gray sandy, fossils (see table 1) _............. 1

6. Shale, black …_..... 1

5. Bentonite 


\section{Section of part of the Carlile shale-Continued}

Lower unnamed member-Continued

Feet Inches

4. Shale, black

3. Concretions, sandy, calcareous, fossiliferous (see table 1) _- 1

2. Bentonite

1. Shales, gray to black; poorly exposed. $45(?)$

Lower unnamed member 103

Total 120

Greenhorn formation.

\section{QUATERNARY DEPOSITS}

TERRACE GRA VEL

Terrace gravels are most abundant in the Dewey quadrangle along the western foot of the Elk Mountains and on the top of the wooded ridge west of Dewey. These terrace gravels consist of cobbles and boulders, as large as 6 inches in diameter, in a sandy matrix. The terrace gravels along the valley of Line Creek dip gently to the south. Their altitude in the north end of the quadrangle is nearly 4,000 feet; near Dewey their altitude is about 3,700 feet. The gravels form thin caps as much as 10 feet thick on top of the bedrock.

The gravels contain fragments of many rock types, including the sandstones of the Inyan Kara. The age of these gravels is not precisely known, but they are probably of Quaternary age.

\section{LOESS}

Eolian deposits of unconsolidated silt and sand form a thin mantle over several small areas in the southwest corner of the Dewey quadrangle. These deposits are brown gray and probably do not exceed 5 feet in thickness. The unconsolidated material stands up in vertical banks and is well exposed in the cut along the paved road south of the bridge over Beaver Creek in sec. 18, T. 41 N., R. 60 W.

\section{ALTUVIUM}

Alluvium of Quaternary age covers the valley bottoms of Line and Beaver Creeks and parts of the tributary valleys that extend into the Elk Mountains. The alluvium in most places is probably not more than 25 feet thick. The material consists of clay, silt, and sand with some gravel up to boulder size.

\section{LANDSLIDE DEBRIS}

Landslide debris is common on the steep east face of the Elk Mountains and in the canyons incised into the dip slope that forms the west 
side of the Elk Mountains. Some slides are large enough to map at a scale of 1:24,000-notably those on the northwest side of Triangle Park, on the east side of the bowl-shaped valley that lies within half a mile west of Sullivan Peak, and on the south end of the Elk Mountains east of Dewey in sec. 9, T. 6 S., R.1 E.

\section{STRUCTURAL GEOLOGY}

The major structures of the southwest flank of the Black Hills in the Dewey area are two monoclines separated by a structural terrace. The monocline along the east side of the quadrangle is cut by a series of echelon faults. These and other features of the western flanks of the Black Hills are shown in figure 5 .

Two stratigraphic horizons were used in determining the structure shown on plate 5. West of Line Creek (dashed contour lines), the datum is the top of a sandstone zone 50 feet above the base of the Mowry shale; east of Line Creek (solid contour lines), the datum is the base of the $S_{5}$ sandstone of the Fall River formation at 400 to 425 feet below the Mowry datum. South of the Dewey fault, the contour lines are interpretive because neither datum is well exposed. To preserve the continuity of the map, the contour lines are numbered consecutively relative to the top of the sandstone zone in the Mowry shale. A contour interval of 25 feet was used over most of the area west of Line Creek to show details of the structure which otherwise would be lost with the contour interval of 100 feet used elsewhere.

\section{FOLDS}

In the Dewey quadrangle, two major monoclines are separated by a structural terrace. The Elk Mountains have been cut from westdipping strata of the Black Hills monocline on the east side of the terrace. The rocks strike N. $20^{\circ} \mathrm{W}$. and dip from $3^{\circ}$ to $10^{\circ} \mathrm{W}$.

The Fanny Peak monocline on the west side of the structural terrace is exposed in the Dewey quadrangle for a distance of only 1 mile in the extreme northwest corner of the area. Here the monocline strikes generally N. $10^{\circ} \mathrm{E}$. and dips $25^{\circ} \mathrm{W}$. This monocline forms the structural boundary between the Black Hills uplift on the east and the Powder River Basin on the west.

The structural terrace between the monoclines is known as the Dewey terrace. At the northern boundary of the quadrangle it is about 2 miles wide and at the latitude of Dewey, $51 / 2$ miles wide. The terrace is deformed locally into small anticlines and synclines, but the regional dip over most of the terrace is $1^{\circ}$ to $2^{\circ} \mathrm{W}$. 


\section{FAULTS}

The major faults in the area are the two echelon faults near Dewey that strike N. $50^{\circ}$ to $60^{\circ} \mathrm{E}$. The dips are apparently nearly vertical. The fault that passes through Dewey-the Dewey fault-begins in the Elk Mountains, about $21 / 2$ miles northeast of Dewey. The fault appears to be continuous for at least $61 / 2$ miles. Measurable vertical displacement on the fault is about 60 feet on the dip slope of the mountain but is at least 200 feet in secs. 21,22 , and 28 , T. 41 N., R. $60 \mathrm{~W}$.

About one-half mile southeast of the Dewey fault is another fault that probably ends south of Dewey; it has been traced northeastward for about 2 miles. This fault also has a large component of vertical movement; the southeast block has moved down in relation to the northwest block. Exact measurements cannot be made because of landslide debris, but the maximum displacement is about 225 feet.

Many other smaller faults were mapped in the quadrangle (pl. 5). Most of these faults appear to be nearly vertical and of small vertical displacement, mostly less than 20 feet. Horizontal components also are probably small. Most of these faults are mappable because of good exposures of good marker beds-the sandstone in the Mowry and the oligonite beds in the lower 50 feet of the Belle Fourche shale. These faults would seem to indicate that the structure of the Dewey terrace is complicated in detail. Many other small faults are probably present, but are not discernible because of poor exposures.

A subsurface fault zone $11 / 2$ miles long and about 400 feet wide was found by seismic methods in secs. 16 and 21 , T. 5 S., R. 1 E. (pl. 5). The zone trends N. $35^{\circ} \mathrm{E}$. Near its southwest end the zone splits in two and dies out in Triangle Park.

\section{JOINTS}

The rocks of the Dewey quadrangle are cut by two major sets of joints. The most conspicuous set strikes northeast. In the southwestern part of the quadrangle the strike is N. $45^{\circ}$ to $60^{\circ} \mathrm{E}$.; in the northeastern part of the quadrangle, the joints strike N. $10^{\circ}$ to $45^{\circ} \mathrm{E}$. Most of the joints dip more than $60^{\circ} \mathrm{NW}$. or SE. and many are vertical. A less conspicuous set of joints strikes N. $10^{\circ}$ to $40^{\circ} \mathrm{W}$. This set also has steep to vertical dips.

The trends of the canyons which cut across the ridge of the Elk Mountains are perhaps controlled by the northeast-striking set of joints. 


\section{ECONOMIC GEOLOGY}

\section{URANIUM DEPOSITS}

Scattered radioactivity anomalies and occurrences of uranium minerals have been found in the Fall River formation in the Elk Mountains. Small prospect pits and trenches are scattered along the dip slope of the mountains. Many of these were excavated because of weak radioactivity anomalies; others are not abnormally radioactive.

A few occurrences of uranium minerals were found in the Lakota formation mostly in the $S_{3}$ sandstone in the cliffs in the SW1/4 sec. 21, T. 5 S., R. 1 E.

\section{WICKER-BAIDWIN PROSPECT}

Of the uranium occurrences in the Dewey quadrangle, only the Wicker-Baldwin property in the NE1/4 sec. 16, T. 42 N., R. 60 W., Weston County, Wyo., has been developed (pl. 5).

Underground workings totaling 340 feet (pl. 6) were made between August 1955 and September 1956. All the workings are in the $\mathrm{S}_{5}$ sandstone of the Fall River formation. The host rocks strike N. $32^{\circ}$ W. and $\operatorname{dip} 8^{\circ} \mathrm{SW}$. The sandstone unit, which is at least 60 feet thick, is white, gray, and yellow to rusty brown, and generally medium grained. Included in the sandstone are fragments, layers, and pods of carbonaceous clay, lignite, clay fragments, conglomerate, pyritic clay, and calcareous concretions as much as 6 feet across.

\section{IITHOLOGY OF HOST ROCKS}

Five major lithologic units are distinguishable in the $S_{5}$ sandstone at the prospect. The relation of these units is shown in the diagrammatic section (pl. 6) of the northwest wall of the main drift.

Unit A is massive to crossbedded medium-grained sandstone. The unit is generally gray to yellow and contains spherical or oblate concretions of white calcareous sandstone and local lenses or beds of clay gall conglomerate. Isolated crystals of pyrite and disseminated flecks of carbonaceous material are common. The rocks of this unit contain little radioactive material.

The most characteristic structures of this unit are the large concretions of calcareous sandstone, some of which are shown in the diagrammatic section on plate 6 . The larger concretions are about 6 feet in diameter and contain principally concentric gray to brown rims around a core of white quartzose medium-grained calcareous sandstone. These concretions seem to have no associated radioactivity. 
The concretion 50 feet from the portal in the diagrammatic section contains a dark outer rim of medium-grained quartz sand about 2 inches thick. The rim is largely noncalcareous, is stained by iron oxides, and contains flecks of carbonaceous matter. Between the rim and the core is a zone of white quartz sand that is noncalcareous and friable. Carbonaceous matter also is disseminated in this zone. The core is white calcareous quartzose sandstone containing small pods and thin partings of calcareous pyritic clay and flecks and partings of carbonaceous matter. The core is well cemented by calcite, as contrasted with the friable sandstone of the outer zones and the enclosing rock beyond. The concretions next to the lignite of unit $\mathrm{B}$ are truncated sharply and do not extend into or beyond the underlying lignite as shown on the diagrammatic section.

Unit B varies from a black bed of lignitic clay to a zone of white poorly cemented sand. The sand zone contains abundant carbonaceous matter, such as disseminated fragments or pods 8 to 10 feet long and as much as 1 foot thick. The thin lignitic bed, from 1 to 3 feet thick, also contains some scattered crystals of pyrite and red to brown iron oxides in pods a few inches across and as coatings along fractures. To the east and south this lignitic bed gives way to the zone of white carbonaceous sandstone that is as much as 5 feet thick.

The contacts of unit $B$ with those above and below are sharp. On the west wall of the south drift (not shown in the diagrammatic section on pl. 6) this unit merges with the lower carbonaceous sandstone of unit $\mathrm{D}$ where unit $\mathrm{C}$ pinches out.

Unit $\mathrm{C}$ is yellow to brown medium-grained poorly cemented sandstone. It ranges in thickness from 2 to about 10 feet. Small widely scattered pods of sandstone 1 to 3 inches across contain yellow uranium minerals interstitial to sand grains. Some carbonaceous matter is disseminated in the unit. In the northwest stope some carbonaceous material is radioactive, but no uranium minerals have been identified.

Unit D consists of white to rusty-brown friable sandstone with pods and flecks of carbonaceous matter, layers of lignite with pods of finely divided pyrite and iron oxides, gray carbonaceous siltstone, mudstone with sandy partings, and sandstone with pods of clay gall conglomerate. These lithologic units, especially the fine-grained clayey and lignitic beds, are contorted in gentle minor folds and contain many slickensides that extend for a few inches or less in a direction roughly parallel to bedding. Some of the white sandstones contain diffusion bands of iron oxide, indicative of movement of iron in these rocks. 


\section{URANIUM MINERALS}

Scattered occurrences of yellow carnotite-type minerals are associated with the rusty-brown sandstones of units B-D.

Not all the radioactive anomalies in these sandstones are traceable to identifiable uranium minerals. A radioactive sample of ferruginous sandstone from unit $\mathrm{C}$ contains no uranium minerals visible to the unaided eye. After disaggregation and concentration by the Frantz separator, the most radioactive material was found to occur as red anisotropic grains of resinous luster that give a positive reaction in the flux test for uranium. Qualitative spectrographic tests indicate that the chief constituents are iron and vanadium and some titanium and uranium (J. W. Adams, oral communication, 1956). Results of $\mathrm{X}$-ray work indicate that the material is amorphous. Cubes of jarosite pseudomorphous after pyrite are associated with the red uraniferous mineral in the magnetic part of the $-200+400$-mesh fraction of the sample.

Uraniferous material is associated with the carbonaceous and lignitic material of units B-D, but no specific uranium minerals were found. The uranium perhaps is fixed chemically in some complex organic compound.

\section{GEOLOGIO ENVIRONMENT}

It was previously suggested that the $S_{5}$ sandstone was of channel origin (see descriptions of Fall River formation above). The many closely associated units of different composition observed at the Wicker-Baldwin prospect suggest that the mine workings penetrate a sequence of heterogeneous sedimentary materials such as might be deposited on the fill side of a bend in a river channel. The interpretation that the prospect is located near the edge of the channel is corroborated by exposures in the various canyons within 1 mile east of the prospect where the thick channel sandstone thins and interfingers with other rocks.

\section{ORIGIN AND LOCALIZATION OF URANIUM MINERALS}

The ultimate origin of the uranium in the rocks of the Inyan Kara group is unknown. Evidence for and against various hypotheses for the origin of uranium minerals in many deposits of the world has been discussed by McKelvey, Everhart, and Garrels (1955) and many other authors in the report compiled by Page, Stocking, and Smith (1956).

Although how the uranium entered the rocks of the southern Black Hills is not known, the uranium has obviously been localized into scattered occurrences and ore deposits. The geologic features of the localizations can be summarized as follows: 
1. The most favorable host rocks are the permeable sandstones, many of channel origin, in the Inyan Kara group. These rocks generally contain carbonaceous matter and iron compounds, particularly oxides; the sulfate jarosite; and the sulfides pyrite and marcasite.

2. Many deposits are found in the areas of gently dipping rocks between more steeply dipping rocks.

3. Most of the deposits contain yellow carnotite-type uranium minerals indicative of oxidized deposits. Black uranium minerals of the unoxidized type are rare. In the southern Black Hills, only the Triangle mine in the Burdock quadrangle and the Runge mine in the Edgemont NE quadrangle are yielding black ore. The extent of oxidized and unoxidized ore may be related to the position of the water table. If the original ores were composed of black unoxidized minerals, these probably would persist below the water table. If the water table dropped, the black ores remaining above the lowered water table would be oxidized.

4. Gott (1956) has reported a possible correlation of ore deposits with the margins of bodies of sandstone cemented by carbonate minerals. The application of this correlation resulted in the discovery of the Runge mine in the Edgemont NE quadrangle.

POSSIBILITIES FOR FURTHER EXPLORATION

Applying the criteria described in the previous section, the Dewey terrace west of the Elk Mountains might contain some deposits of uranium. The valley of Line Creek from the Dewey fault northward (pl. 5) should probably be of primary interest at the beginning of an exploration program.

The geology at the Wicker-Baldwin prospect is a clue. The prospect is near the western foot of the Elk Mountains in the $S_{5}$ sandstone. Here the sandstone of channel origin dips $8^{\circ} \mathrm{W}$. and is mineralized. The mineralized parts of the sandstone are east of the thickest part of the channel filling, which is commonly 1 to 2 miles wide. The other side of the channel, therefore, probably extends west of the prospect onto the Dewey terrace where the rocks dip less than $5^{\circ} \mathrm{W}$. The trend of this channel roughly follows the trace of the change in dip from the hogback of the Elk Mountains to the terrace. Thus, favorable host rocks known to be mineralized meet with favorable structure at a change in dip along the valley of Line Creek.

In the valley of Line Creek, the rocks of the Inyan Kara group are covered by the Skull Creek shale and river alluvium; the thick- 
ness of the cover probably does not exceed 250 feet on the west side of the valley and becomes progressively thinner toward the east side. The top of the $S_{5}$ sandstone is probably 70 feet below the top of the Inyan Kara. The rocks of the Lakota formation also might contain some uranium deposits in this area. The lithology of these rocks over most of the Dewey terrace, however, is completely unknown.

The Inyan Kara on other parts of the terrace also might contain uranium, but these deposits would be buried deeper. At the western margin of the Dewey terrace, the Inyan Kara is overlain by nearly 1,000 feet of black shales of the Skull Creek, Mowry, and Belle Fourche.

The nature of the uranium minerals in any deposits on the Dewey terrace would depend partly upon their relation to the water table. The position of the water table would govern the oxidation state of the minerals and the position of any zone of secondary enrichment. Uranium moving within the $S_{5}$ channel unit might be expected to stay mainly within that unit because of the lower permeability of the enclosing mudstones and siltstones. Thus, it would seem possible that water moving through the $S_{5}$ sandstone could dissolve and carry uranium down the dip of the Elk Mountains where it might be reprecipitated and concentrated near the water table in the same stratigraphic unit on the Dewey terrace.

In summary, a potentially favorable area for uranium deposits is in the Inyan Kara rocks on the Dewey terrace. The $S_{5}$ sandstone of the Fall River formation is mineralized at places and is exposed or at shallow depth on the east side of the terrace.

The potential uranium production from the Lakota in the Dewey quadrangle cannot be estimated. The Lakota is poorly exposed in the Elk Mountains and is considerably less exposed than the Fall River (pl. 5). Occurrences of uranium minerals within the Lakota are rare. The detailed lithology of this unit on the Dewey terrace is completely unknown.

\section{BENTONITE}

Bentonite beds from a few inches to 2 feet thick are interlayered with the black shales on the Dewey terrace, especially in the upper 25 feet of the Mowry shale and the lower 50 feet of the Belle Fourche shale. The beds have been prospected extensively. The larger prospects are shown on the geologic map (pl. 5). These beds of bentonite are not of commercial value under current economic conditions (1959), chiefly because of their thinness and the large amounts of overburden. 


\section{SAND AND GRAVEL}

Sand and gravel are available in the area from terraces along the valley of Line Creek at the western foot of Elk Mountain and from cappings on the tops of the low hills on the Dewey terrace. The deposits probably do not exceed 10 feet in thickness.

\section{OIL AND GAS}

Several wells were drilled for oil on the Dewey terrace. One well near the center of sec. 7, T. 41 N., R. $60 \mathrm{~W}$., produced some oil from in the Minnelusa formation of Pennsylvanian age, the top of which is 2,000 feet below the surface of this area. This well and another in the same section are now yielding artesian water (center of sec. 7, T. 41 N., R. 60 W.).

Small areas of structural closure which might be traps for oil and gas are in part of sec. 9, T. 41 N., R. 60 W., and sec. 19, T. 41 N., R. $60 \mathrm{~W}$. These closures were determined by surface features; their persistence at depth, relation to buried unconformities, and relation to wedging of sedimentary rocks are unknown.

The function of ground water in the entrapment of oil on the Dewey terrace was not investigated, but application of the principles of entrapment of oil and gas under hydrodynamic conditions described by Hubbert (1953) might suggest areas for further drilling.

\section{LITERATURE CITED}

Brobst, D. A., 1958a, Preliminary geologic map of the northeast part of the Dewey quadrangle, Custer County, S. Dak., and Weston County, Wyo.: U.S. Geol. Survey Mineral Inv. Map MF-77.

1958b, Preliminary geologic map of the east-central part of the Dewey quadrangle, Custer County, S. Dak.: U.S. Geol. Survey Mineral Inv. Map MF-78.

Cobban, W. A., 1951, Colorado shale of central and northwestern Montana and equivalent rocks of the Black Hills : Am. Assoc. Petroleum Geologists Bull., v. 35, no. 10, p. 2170-2198.

Collier, A. J., 1922, The Osage oil field, Weston County, Wyoming: U.S. Geol. Survey Bull. 736-D, p. 71-110.

Darton, N. H., 1899, Jurassic formations of the Black Hills of South Dakota: Geol. Soc. America Bull., v. 10, p. 383-396.

1901a, Preliminary description of the geology and water resources of the southern half of the Black Hills and adjoining regions of South Dakota and Wyoming: U.S. Geol. Survey 21st Ann. Rept., pt. 4, p. 489-599.

-1901b, Comparison of stratigraphy of the Black Hills with that of the Front Range of the Rocky Mountains: Am. Jour. Sci., new ser., v. 13, no. 318, p. 188.

- 1904, Description of the Newcastle quadrangle [Wyoming and South Dakota ] : U.S. Geol. Survey Geol. Atlas, Folio 107, 9 p.

Gilbert, G. K., 1896, The underground water of the Arkansas valley in eastern Colorado: U.S. Geol. Survey 17th Ann. Rept., pt. 2, p. 551-601. 
Gott, G. B., 1956, Inferred relationship of some uranium deposits and calcium carbonate cement in southern Black Hills, South Dakota: U.S. Geol. Survey Bull. 1046-A, p. 1-8.

Grace, R. M., 1952, Stratigraphy of the Newcastle formation, Black Hills region, Wyoming-South Dakota: Geol. Survey Wyoming Bull. 44, 44 p.

Hancock, E. T., 1920, The Mule Creek oil field, Wyoming :U.S. Geol. Survey Bull. 716-C, p. 35-53.

Hubbert, M. King, 1953, Entrapment of petroleum under hydrodynamic conditions : Am. Assoc. Petroleum Geologists Bull., v. 37, p. 1954-2026.

Imlay, R. W., 1947, Marine Jurassic of the Black Hills area, South Dakota and Wyoming: Am. Assoc. Petroleum Geologists Bull., v. 31, no. 2, p. 227-273.

Knechtel, M. M., and Patterson, S. H., 1956, Bentonite deposits of the northern Black Hills district, Montana, Wyoming, and South Dakota: U.S. Geol. Survey Mineral Inv. Map MF-36.

Krumbein, W. C., 1941, Measurement and geological significance of shape and roundness of sedimentary particles: Jour. Sed. Petrology, v. 11, p. 64-72.

McKelvey, V. E., Everhart, D. L., and Garrels, R. M., 1955, Origin of uranium deposits, in Pt. 1 of Bateman, A. M., ed., Econ. Geology 50th Anniversary Volume: p. 464-534.

Noble, J. A., Harder, J. O., and Slaughter, A. L., 1949, Structure of a part of the northern Black Hills and the Homestake mine, Lead, S. Dak.: Geol. Soc. America Bull., v. 60, p. 321-352.

Page, L. R., Stocking, H. E., and Smith, H. B., compilers, 1956, Contributions to the geology of uranium and thorium by the United States Geological Survey and Atomic Energy Commission for the United Nations International Conference on the peaceful uses of atomic energy, Geneva, Switzerland, 1955 : U.S. Geol. Survey Prof. Paper 300.

Peterson, J. A., 1954, Marine Upper Jurassic, eastern Wyoming: Am. Assoc. Petroleum Geologists Bull., v. 38, no. 4, p. 463-507.

Post, E. V., and Bell, Henry III, 1961, Chilson member of the Lakota formation in the Black Hills, South Dakota and Wyoming; in Short papers in the geologic and hydrologic sciences: U.S. Geol. Survey Prof. Paper 424-D, art. 349 (in press).

Rubey, W. W., 1929, Origin of the siliceous Mowry shale of the Black Hills region: U.S. Geol. Survey Prof. Paper 154-D, p. 153-170.

1930, Lithologic studies of fine-grained upper Cretaceous sedimentary rocks of the Black Hills region: U.S. Geol. Survey Prof. Paper 165-A, p. 1-54.

Russell, W. L., 1927, Origin of the sandstone dikes of the Black Hills region: Am. Jour. Sci., 5th Ser., v. 14, p. 402-408. 1928, The origin of artesian pressure : Econ. Geology, v. 23, no. 2, p. 132157.

Waagé, K. M., 1959, Stratigraphy of the Inyan Kara group in the Black Hills: U.S. Geol. Survey Bull., 1081-B, p. 11-90.

Yen, Teng-Chien, 1952, Molluscan fauna of the Morrison formation; with a summary of the stratigraphy of the Morrison formation by J. B. Reeside, Jr.: U.S. Geol. Survey Prof. Paper 233-B, p. 21-51. 


\section{INDEX}

Acknowledgments.............................
Alluvium

Beaver Creek

$16,47,49$

Belle Fourche shale................ 17, 18-19, 47-48, 56

Bentonite $19,21,45,47,48,49,56$

Black Hills monocline

\section{Camptonectes sp.}

Canyon Springs sandstone member of the Sundance formation

Carlile shale $17,18-19,48-49$

Carlile shale hogback

Channel sandstones $32,37,39,40-41,54,55,56$

Chilson member of Lakota formation.- 20-21, 27, 28,

Clay Spur bentonite bed

Cobban, W. A., fossils identified by.

Collignonoceras woolgari

Concretions, calcareous, in Ss sandstone of the

Fall River Formation. 52-53

in Skull Creek shale.................... 21, 45 calcite-cemented sandstone............... 38

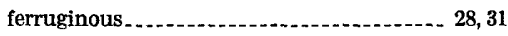
oligonite

Darwinula sp

Dewey 16,51

Dewey fault....................... 33, 45, 47,50,51

Dewey terrace... $13,16,17,19,44,45,47,50,51,55,56,57$

Dikes, sandstone.

$21,44-45$

Echinochara spinosa.

Elk Mountains ._- $16,17,21,23,24,25,27,28,30,32,33$, $37,38,40,42,49-50,51,55,56,57$

Fall River formation of Inyan Kara group... 20-21, $26-30,37-44,52$

Fall River sandstone 26,27

Fanny Peak monocline................... 13, 16,50

Fieldwork

16

Fuson member of Lakota formation... 20-21, 27, 28,

Fuson shale

$29,32-37$

Gas, entrapment.

Gravel, terrace.

Greenhorn formation

$17,18-19,48$

Greenhorn hogback $17,19,48$

Hulett sandstone member of Sundance formation. 22-23, 24

Inoceramus fragilio

Inyan Kara group
Lak member of Sundance formation ....... 22-23,24 Lakota formation of Inyan Kara group ... 20, 26-27,

$29-37,52,56$

Lakota sandstone. ............ 26-27

Landslide debris............................... 49-50

Latochara latitruncata...................... 25

Line Creek. ....................... 16,44, 49, 50,55, 57

Loess................................................ 49

Lucky Strike bentonite prospect. . . ........ 48

M W Lake.. 48

Mapel, W. J., fossils collected by .......... 25

"Metacypris" spp.............................. 25

Minerals, Belle Fourche shale.............. 47-48

Morrison formation...................... 25

S3 sandstone of Fuson member of Lakota formation.................... 33, 34, 36

S4 sandstone of Fuson member of Lakota

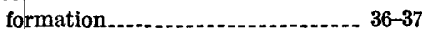

S5 sandstone of Fall River formation.. 38, 52, 53 Skull Creek shale......................... 44-45

upper unit of Fall River formation....... 42-43

Minnewaste limestone....................... 26

Minnewaste member of Lakota formation. 20-21,27 Morrison formation ........... 17, 22-23, 24-26, 29, 33 Mowry shale ............... 17, 20-21, 44, 45, 47, 50, 56

Newcastle sandstone $\ldots . . . . . . . . . . . . . ~ 17,20-21,44-45$

Oil, Dewey terrace............................ 57

entrapment................................ 57

Ostrea stringilecula

Peck, R. E., fossils identified by ......... 25

Plum Canyon

Powder River Basin........................ 13,50

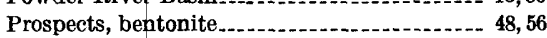

uranium _............ 52

Precambrian rocks............................. 13

Rainfall ...

Redwater shale member of Sundance formation.................. 22-23, 24, 26, 32, 33

$S_{1}$ sandstone of Chilson member of Lakota formation............ 21, 27, 28, 30,31, 32

S3 sandstone of Fuson member of Lakota formation...... 21, 27, 28, 30, 31, 32, 33-35, 52

$\mathrm{S}_{4}$ sandstone of Fuson member of Lakota formation............ 21, 27, 28, 29, 32, 36-37 S6 sandstone of Fall River formation........ 21,27, $28,37,38-41,43,50,52-53,54,56$ Sage Breaks shale member of Carlile shale_18-19, 48 Sand and gravel............................. 57 Sandstones, fossiliferous siliceous ....... 21, 45 Scaphites larvaeformensis. 
Skull Creek shale $17,20-21,44-45,46,56$

Sohn, I. G., fossils identified by

Sundance formation

Page

Spearfish formation.....-. 17, 22-23, 24

Stockade Beaver shale member of Sundance

formation

22-23, 24

Stratigraphic sections, Carlile shale

Fall River formation

$42,43-44$

Inyan Kara group................. 27-28

Lakota formation.

Morrison formation

Redwater shale member of Sundance formation

Spearfish formation

$16,31,50 \mid$ Wicker-Baldwin prospect

$17,22-23,24$

Topography

Tragodosmoceras n. sp.................... 19

Triangle Park

Turner sandy member of Carlile shale

Uranium minerals, Dewey terrace............. $\quad 56$ S3 sandstone of Fuson member of Lakota

formation...................... 34, 52,56

Ss sandstone of Fall River formation... $38,52,54$

Sullivan Peak

Wells, oil

57

prospect....... 38, 40,42, 43,52-55 